\title{
Aspirin modulates the inflammatory response in a thrombus-stimulated LMVEC model
}

\author{
LINGCONG WANG $^{1 *}$, RONGBIAO YING ${ }^{2 *}$, HUIFANG JIANG ${ }^{3 *}$, QUN JIN $^{4 *}$, \\ JING KUANG $^{5}$, ZHIRONG ZHANG ${ }^{1}$, YING SHI ${ }^{1}$, DANLI CAI ${ }^{1}$ and RUHUI YANG ${ }^{6}$
}

\author{
${ }^{1}$ Department of ICU, The First Affiliated Hospital of Zhejiang Chinese Medical University, Hangzhou, Zhejiang 310006; \\ ${ }^{2}$ Department of Surgical Oncology, Tumor Hospital of Taizhou, Wenling, Zhejiang 317502; \\ ${ }^{3}$ Department of Hematology, Tongde Hospital of Zhejiang Province, Hangzhou, Zhejiang 310012; \\ ${ }^{4}$ Department of Pneumology, Zhejiang University International Hospital, Shulan (Hangzhou) Hospital, \\ Hangzhou, Zhejiang 310000; ${ }^{5}$ Zhejiang Chinese Medical University, Hangzhou, Zhejiang 310053; \\ ${ }^{6}$ Lishui University, Lishui, Zhejiang 323000, P.R. China
}

Received October 9, 2017; Accepted March 9, 2018

DOI: $10.3892 /$ ijmm.2018.3561

\begin{abstract}
The purpose of the present study was to examine whether aspirin interferes with the inflammatory response in a thrombus-stimulated lung microvascular endothelial cell (LMVEC) model. The LMVECs were randomly divided into eight groups: Normal group (group N), model group (group $\mathrm{M})$, model + ASP group (group $\mathrm{M}+\mathrm{A}$ ), model+CX3CL1-short hairpin (sh)RNA group (group M+SH), model + CX3CL1-overexpression vector group (group $\mathrm{M}+\mathrm{CX} 3$ ), model + ASP + shRNA group (group $\mathrm{M}+\mathrm{A}+\mathrm{SH}$ ), model + ASP + CX3CL1-overexpression vector group (group $\mathrm{M}+\mathrm{A}+\mathrm{CX} 3$ ), and normal + virus control group (group $\mathrm{N}+\mathrm{V}$ ). The endothelial cells were cultured, and a thrombus was added to the cells. Briefly, $12 \mathrm{~h}$ following the precipitation of the thrombus, data from ELISA, reverse transcription-quantitative polymerase chain reaction analysis and confocal microscopy revealed that the levels of tumor necrosis factor (TNF)- $\alpha$, interleukin (IL)-6, CX3C chemokine ligand 1 (CX3CL1), $\mathrm{CX} 3 \mathrm{C}$ chemokine receptor 1 (CX3CR1) and nuclear factor- $\mathrm{\kappa B}$ $(\mathrm{NF}-\mathrm{\kappa B})$ in group $\mathrm{M}$ were increased, compared with those in group $\mathrm{N}(\mathrm{P}<0.01)$. These levels, with the exception of TNF- $\alpha$, were significantly lower in group $\mathrm{M}+\mathrm{SH}$, compared with those in group $\mathrm{M}(\mathrm{P}<0.01)$. Furthermore, the levels of IL-6 in groups
\end{abstract}

Correspondence to: Dr Lingcong Wang, Department of ICU, The First Affiliated Hospital of Zhejiang Chinese Medical University, 54 Youdian Road, Hangzhou, Zhejiang 310006, P.R. China

E-mail:wlc501@139.com

${ }^{*}$ Contributed equally

Abbreviations: APE, acute pulmonary embolism; LMVECs, lung microvascularendothelial cells

Key words: aspirin, thrombus, lung microvascular endothelial cells, inflammation
$\mathrm{M}+\mathrm{A}, \mathrm{M}+\mathrm{CX} 3$ and $\mathrm{M}+\mathrm{A}+\mathrm{CX} 3$ were decreased, compared with those in group $\mathrm{M}(\mathrm{P}<0.01)$; the level of TNF- $\alpha$ in group $\mathrm{M}+\mathrm{A}+\mathrm{SH}$ was decreased, compared with that in group $\mathrm{M}$ $(\mathrm{P}<0.01)$; the level of $\mathrm{CX} 3 \mathrm{CR} 1$ waslower in groups $\mathrm{M}+\mathrm{A}$ and $\mathrm{M}+\mathrm{A}+\mathrm{SH}$, compared with that in group $\mathrm{M}(\mathrm{P}<0.01)$, and the level of NF- $\mathrm{KB}$ in group $\mathrm{M}+\mathrm{SH}$ was decreased, compared with the level in group $\mathrm{M}$ and group $\mathrm{M}+\mathrm{A}(\mathrm{P}<0.05)$. In conclusion, the thrombus-stimulated LMVEC model exhibited induced production of TNF- $\alpha$, IL-6, CX3CL, CX3CR1, $\mathrm{NF}-\kappa \mathrm{B}$ and intercellular adhesion molecule-1. Furthermore, it was confirmed that the signaling pathways involving CX3CL1-NF- $\kappa B$, IL- 6 and TNF- $\alpha$ were partly inhibited by aspirin.

\section{Introduction}

Acute pulmonary embolism (APE) refers to the blockage of at least one vessel in the lungs, which occurs due to thrombus lodging and leads to disrupted pulmonary circulation. The pathological mechanisms of APE include endothelial injury, activation of the coagulation cascade, inflammation, and the promotion of thrombus formation via inflammatory cell recruitment $(1,2)$. APE-associated inflammation has been somewhat neglected in investigations over previous years, and there are limited reports on the condition. Our previous studies demonstrated that a wide range of inflammatory responses, including the expression of tumor necrosis factor- $\alpha$ (TNF- $\alpha$ ), interleukin (IL)-1 $\beta$, IL-8, the irregular chemokine CX3C chemokine ligand 1 (CX3CL1) and its receptor $\mathrm{CX} 3 \mathrm{C}$ chemokine receptor 1 (CX3CR1) were found in an APE rat model. In addition, the level of CX3CL1 was shown to positively correlate with the level of TNF- $\alpha(3,4)$. It was also found that lipopolysaccharide (LPS) can induce the expression of nuclear factor (NF)- $\mathrm{BB}$ and CX3CL1 in human bronchial epithelial cells (5), and it was found that aspirin improved the pathological changes in rats with APE via the CX3CL1/CX3CR1 signaling pathway $(3,4)$. Based on these findings, adenovirus vectors carrying CX3CL1-short hairpin (sh)RNA and 
CX3CL1-overexpression vectors were constructed in the present study to identify the thrombus-induced inflammatory response involving lung microvascular endothelial cells (LMVECs) at the cellular level, and examine the intervention effect of aspirin.

\section{Materials and methods}

Materials. Aspirin enteric-coated tablets were purchased from Nanjing Baijingyu Pharmaceutical Co., Ltd. (Nanjing, China; specifications: $25 \mathrm{mg}$ x100 tablets/bottle, batch no. 141201).

Western blot analysis. Western blot analysis was used to detect NF- $\mathrm{BB}$. A PVDF membrane was obtained from EMD Millipore (Billerica, MA, USA); cat. no. IPVH00010; batch no. K5JA5013L). Anti-NF-kB p65 antibody was obtained from Abcam (Cambridge, MA, USA; cat. no. ab7970). $\beta$-actin was purchased from Multi Sciences (Lianke) Biotech, Co., Ltd. (cat. no. ab008-100). Goat anti-rabbit IgG was bought from Multi Sciences (Lianke) Biotech, Co., Ltd. (cat. no. GAR0072). Goat anti-mouse IgG was obtained from Bioworld Technology, Inc. (St. Louis Park, MN, USA; cat. no. BS12478). An electrophoresis system (Mini-Proten Tetra system) was purchased from Bio-Rad Laboratories, Inc. (Hercules, CA, USA). A gel imager was obtained from Bio-Rad Laboratories, Inc. (ChemiDoc XRS+ system).

Reverse transcription-quantitative polymerase chain reaction (RT-qPCR) analysis. RT-qPCR analysis was performed to detect the expression levels of CX3CL1, CX3CR1, IL-6 and TNF- $\alpha$. A highly purified total RNA rapid extraction kit was purchased from Generay (cat. no. GK3016; batch no. 1512G14). A reverse transcription kit (Prime Script ${ }^{\mathrm{TM}}$ RT reagent) was obtained from Takara Bio, Inc. (Otsu, Japan; cat. no. RR037A; batch no: AK5102). qPCR reagent, Super RealPreMix Color (SYBR Green), was purchased from Tiangen Biotech Co., Ltd. (Beijing, China; cat. no. FP215-02; batch no. O3911). Instrumentation for optical density (OD) measuring (high-precision spectrophotometer SMA4000) was purchased from Merinton Instrument, Inc. (Ann Arbor, MI, USA). The machine used for qPCR was the CFX connect Real-Time PCR system, and the software used for analysis was BIO-RAD CFX Manager 3.1 (Bio-Rad Laboratories, Inc.).

ELISA. ELISA was used to evaluate the levels of IL-6, TNF- $\alpha$ and intercellular adhesion molecule-1 (ICAM-1). The IL-6 ELISA kit was purchased from USCN (cat. no. SEA079Ra, batch no. L160301015). The TNF- $\alpha$ ELISA kit was purchased from USCN Life Science, Inc. (Wuhan, China; cat. no. SEA133Ra, batch no. L160301011). The ICAM-1 ELISA kit was purchased from USCN (cat. no. SEA548Ra, batch no. L160301001).

Laser confocal microscopy. Laser confocal microscopy was used to determine the co-expression of 3CL1/CX3CR1 and CX3CL1/NF- $\kappa$ B. DAPI was purchased from Sigma; EMD Millipore (cat. no. D9452). CX3CL1 antibody was purchased from Santa Cruz Biotechnology Co., Ltd. (Dallas, TX, USA; cat. no. sc-7227). CX3CR1 antibody was obtained from Abcam (cat. no. ab7200). NF-кB p65 antibody was purchased from Abcam (cat. no. ab7970). Alexa Fluor ${ }^{\circledR} 647$ conjugate served as donkey anti-goat $\operatorname{IgG}(\mathrm{H}+\mathrm{L})$ secondary antibody, and Alexa Fluor ${ }^{\circledR} 594$ conjugate served as goat anti-rabbit IgG $(\mathrm{H}+\mathrm{L})$ secondary antibody. The laser confocal microscope (LSM510 Meta) was obtained from Zeiss AG (Oberkochen, Germany).

\section{Methods}

Establishment of an LMVEC model induced by thrombus stimulation (6,7). All animal experiments, including the method of sacrifice, were performed in compliance with the institutional animal care regulations and guidelines of Zhejiang Chinese Medical University (Hangzhou, China) and performed according to the Association for Assessment and Accreditation of Laboratory Animal Care International (AAALAC) and the Institutional Animal Care and Use Committee (IACUC) guidelines. The present study was approved by the Laboratory Animal Management and Ethical Review Committee (no. ZSLL-2015-1015) of Zhejiang Chinese Medical University (Hangzhou, China).

The rat LMVECs were purchased from Pri Cells Biomedical Technology Co., Ltd. (Wuhan, China). Frozen LMVECs were recovered and cultured in LHC-8 serum-free medium (Gibco; Thermo Fisher Scientific, Inc., Waltham, MA, USA) at $37^{\circ} \mathrm{C}$, in a $5 \% \mathrm{CO}_{2}$ incubator. For subculture, the cells were washed with PBS, digested with $0.125 \%$ trypsin $+0.01 \%$ EDTA, and maintained in logarithmic phase culture. For treatment, the cells were digested, counted and seeded in 6-well plates at a density of $2 \times 10^{5}$ per well. Male Sprague-Dawley (SD) rats ( $n=3 ; 8$ weeks old, $200 \mathrm{~g}$ ) were purchased from Shanghai SLAC Laboratory Animal Co., Ltd. (Shanghai, China). The animals were housed with $12 \mathrm{~h}$ dark/light cycles, temperature of $22-26^{\circ} \mathrm{C}$ and atmosphere of $\sim 0.03-0.04 \% \mathrm{CO}_{2}$. Animals were given access to food and water ad libitum. Following a 6-day acclimation, the experiment was initiated. The rats were anesthetized by intraperitoneal injection of $2 \%$ sodium pentobarbital $(0.25 \mathrm{ml} / 100 \mathrm{~g})$; all surgery was performed under sodium pentobarbital anesthesia and all efforts were made to minimize suffering. Rat venous blood was collected, and a thrombus $5 \mathrm{~mm}$ in size was prepared. The LMVECs were randomly divided into two groups $(n=3)$ : Normal group (group N) and model group (group M); the cells in group $\mathrm{N}$ did not receive thrombus stimulation. Thrombosis precipitated naturally (a $2 / 3$ thrombosis pavement was considered a base). Time points of $0,0.5,1,4,8$ and $12 \mathrm{~h}$ were set prior to experiment commencement; the 12-h time point was selected as the appropriate time to wash away the thrombus for measurement based on the pre-experimental data. For each group, experimentation was run in triplicate. ELISA was used to detect IL-6, TNF- $\alpha$ and ICAM-1. RT-qPCR analysis was performed to measure the expression levels of CX3CL1, CX3CR1, IL-6 and TNF- $\alpha$; the primer sequences are listed in Table I. Total RNA was extracted using TRIzol reagent (Thermo Fisher Scientific, Inc.), according to the manufacturer's protocol. A total of $2 \mu \mathrm{g}$ of extracted RNA was converted to cDNA by MMLV-reverse transcriptase (Fermentas; Thermo Fisher Scientific, Inc.), which was usedaccording to its manufacturer's protocol. The cDNA was amplified using the following forward and reverse primers as previously described (8). The mRNA expression of CX3CL1, CX3CR1, IL-6 and TNF- $\alpha$ was determined with qPCR using IQ SYBR Green SuperMix PCR Array kit was purchased from Bio-Rad 
Laboratories, Inc. The following thermo cycling conditions were used for the PCR: 40 cycles of $50.0^{\circ} \mathrm{C}$ for $3 \mathrm{~min}, 95.0^{\circ} \mathrm{C}$ for $15 \mathrm{~min}, 95.0^{\circ} \mathrm{C}$ for $10 \mathrm{sec}, 58.0^{\circ} \mathrm{C}$ for $15 \mathrm{sec}, 72.0^{\circ} \mathrm{C}$ for $15 \mathrm{sec}$. The sequence of primers was as follows: Rat CX3CL1 forward, GCAGTGACTGGATCGTCTCC, rat CX3CL1 reverse, ACT CGGCCAAATGGTGGTAG; rat CX3CR1 forward, AGTTGT GGCATGAAGAGGGAC, rat CX3CR1 reverse, GGGGTT GAGGCAGCAGTG; rat IL6 forward, TTCCAGCCAGTTGCC TTCTT, rat IL6 reverse, TGTTGTGGGTGGTATCCTCTGT; rat TNFa forward, CCACCACGCTCTTCTGTCTACTG, rat TNFa reverse, GGGCTACGGGCTTGTCACTC. The primers were designed and synthesized at Shanghai Generay Biotech (Shanghai, China). The reaction was performed and analysed by a CFX Connect Real-Time PCR System (Bio-Rad Laboratories, Inc). The relative expression levels of the mRNA in each sample were calculated using the $2^{-\Delta \Delta C t}$ method (9). These levels were expressed in arbitrary units.

Western blot analysis was used to evaluate the expression of $\mathrm{NF}-\kappa \mathrm{B}$. Protein samples were extracted from the rat LMVECs using Protein Extraction kit (Beyotime Institute of Biotechnology, Jiangsu, China). The protein concentration was determined using bicinchoninic acid method. Protein samples (30 mg) were separated using $4 \%$ to $12 \%$ Bis-Tris SDS-PAGE gelsand then transferred to polyvinylidene fluoride membranes. Membranse were blocked with 5\% skim milk in PBS/1\% Tween-20 for $1 \mathrm{~h}$ at room temperature. Following incubation PVDF membrane waswashed with $1 \mathrm{X}$ TBST solution for 5 min. The membranes were then incubated with primary antibodies as described above overnight at $4^{\circ} \mathrm{C}$. Subsequently, the membranes were incubated with secondary antibodiesas described above for $2 \mathrm{~h}$ at room temperature. ECL chemiluminescence reagent (Beyotime Institute of Biotechnology) ws used for visualization.

Chemiluminescent images of the blots were finally captured using a ChemiDoc System. ImageJ software was used to calculate the integrated absorbance of identified bands (IA), and the expression of protein was calculated using the following formula: The relative expression of protein $=\mathrm{IA}_{\text {protein }} / \mathrm{IA}_{\beta \text {-actin. }}$.

Laser confocal microscopy was used to evaluate the co-expression of CX3CL1/CX3CR1 and CX3CL1/NF- $\kappa$ B. Fractalkine (CX3CL1) antibody (Santa Cruz Biotechnology, Inc.; 1:10), anti-NF- $\mathrm{B}$ p65 antibody (1:50), anti-CX3CR1 antibody (1:100) (both from Abcam), anti-rabbit IgG secondary antibody (488 conjugate; Thermo Fisher Scientific, Inc.; excitation wavelength/emission wave length: 488/520 nm; 1:200), anti-goat IgG secondary antibody (555 conjugate; Thermo Fisher Scientific, Inc., excitation wavelength/emission wavelength: 555/562 nm; 1:200), and DAPI (Sigma; EMD Millipore; excitation wavelength/emission wavelength: $358 / 461 \mathrm{~nm}$ ) were used.

A fluoresceinisothiocyanate (FITC) labeling kit, which was purchased from Sangon Biotech Co., Ltd. (Shanghai, China), with excitation and emission wavelengths of 490 and $525 \mathrm{~nm}$ respectively, was used to label recombinant protein. The freeze-dried powder of the recombinant protein was dissolved in PBS and mixed with FITC. The sample was then incubated in the dark at room temperature for $5 \mathrm{~h}$. Subsequently, the sample was purified in a gel column, and unbound FITC was removed. A cell climbing slice was prepared, and FITC-labeled CX3CL1/CX3CR1 and CX3CL1/NF- $\kappa$ B were added to the slice and incubated at room temperature for 10 min. Following incubation, the slice was washed with PBS four times. Following mounting of the slice, laser confocal microscopy was used to evaluate the cellular localization of CX3CL1/CX3CR1 and CX3CL1/NF- $\kappa$ B. For staining, CX3CL1 (goat anti human antibodies) was combined with either CX3CR1 (rabbit anti human antibodies) or NF- $\mathrm{B}$ p65 (rabbit anti human antibodies) for double staining. The fluorescent secondary antibody applied to CX3CL1 was donkey anti-goat $\operatorname{IgG}(\mathrm{H}+\mathrm{L})$, secondary antibody ${ }^{\circledR} 647$ (near-infrared; pseudocolor green). The fluorescent secondary antibody

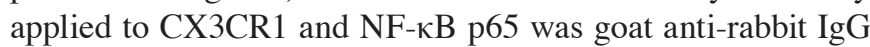
$(\mathrm{H}+\mathrm{L})$, secondary antibody ${ }^{\circledR} 594$ (red). ImageJ 4.1 software (National Institutes of Health, Bethesda, MD, USA) was used to calculate the fluorescence value (unit: pixels): Cell fluorescence intensity $=$ fluorescence value/mean value of group $\mathrm{N}$.

Vector construction. The construction of vectors carrying CX3CL1-overexpression shRNA was performed as an in vitro experiment. Vector pHBAd-MCMV-GFP (Hanbio, Shanghai, China), vector pHBAd-U6-GFP (Hanbio), Escherichia coli strain DH5 $\alpha$ (Tiangen Biotech Co., Ltd.), restriction enzyme, T4 ligase (both from Fermentas Thermo Fisher Scientific, Inc.) and a plasmid DNA extraction kit (CWBio, Beijing, China) were used. The TCID50 method was applied to detect the titer (10). The viral concentration was $\mathrm{MIO}=10$.

Verification of the effect of CX3CL1 on the model. The adenovirus vectors of CX3CL1-overexpression were constructed. The LMVECs were randomly divided into four groups $(\mathrm{n}=3)$ : Normal group (group $\mathrm{N}$ ), model group (group $\mathrm{M}$ ), model + CX3CL1-overexpression vector group (group $\mathrm{M}+\mathrm{CX} 3$ ), and normal + virus control group (group $\mathrm{N}+\mathrm{V}$ ). ELISA was used to determine the levels of IL-6, TNF- $\alpha$ and ICAM-1. RT-qPCR analysis was performed to detect the expression levels of CX3CL1, CX3CR1, IL-6 and TNF- $\alpha$, whereas the cell culture supernatant was separated for ELISA. Western blot analysis was used to measure NF- $\kappa \mathrm{B}$; for which total protein was extracted following washing of the cells with PBS. Laser confocal microscopy was used for evaluation of the co-expression of CX3CL1/CX3CR 1 and CX3CL1/NF- $\kappa$ B.

Verification of the effects of CX3CL1-shRNA on the model. The adenovirus vectors carrying CX3CL1-shRNA were constructed. The LMVECs were randomly divided into four groups ( $\mathrm{n}=3)$ : Group N, group M, model+CX3CL1-shRNA group (group $\mathrm{M}+\mathrm{SH}$ ), and group $\mathrm{N}+\mathrm{V}$.

Verification of the effects of aspirin combined with CX3CL1 on the model. The LMVECs were randomly divided into eight groups $(n=3)$ : Group N, group $M$, model + aspirin group (group $M+A)$, group $\mathrm{M}+\mathrm{SH}$, group $\mathrm{M}+\mathrm{CX} 3$, model + shRNA + aspirin group (group $\mathrm{M}+\mathrm{A}+\mathrm{SH}$ ), model + aspirin $+\mathrm{CX} 3 \mathrm{CL} 1-$ overexpression vector (group $\mathrm{M}+\mathrm{A}+\mathrm{CX} 3$ ), and group $\mathrm{N}+\mathrm{V}$ (Table II).

Statistical analysis. IBM SPSS 21.0 (IBM SPSS, Armonk, NY, USA) was used for statistical analysis. The experimental results are expressed as the mean \pm standard deviation, and two independent samples were compared using the paired $\mathrm{t}$-tests. Single factor analysis of variance was used to compare 
Table I. Primer sequences for reverse transcription-quantitative polymerase chain reaction detection of CX3CL1, CX3CR1, IL-6 and TNF- $\alpha$.

Target gene

Primer sequence (5'-3')

Product size (bp)

Genbank ID: 89808

RatCX3CL1Forward

RatCX3CL1Reverse

GCAGTGACTGGATCGTCTCC

Genbank ID: 171056

ACTCGGCCAAATGGTGGTAG

RatCX3CR1Forward

AGTTGTGGCATGAAGAGGGAC

RatCX3CR1Reverse

GGGGTTGAGGCAGCAGTG

Genbank ID: 25464

RatICAM1Forward

RatICAM1Reverse

ATCATTGCGGGCTTCGTG

AGGGAGGCGGGGCTTGTAC

Genbank ID: 24835

RatTNF- $\alpha$ Forward

CCACCACGCTCTTCTGTCTACTG

150

RatTNF- $\alpha$ Reverse

GGGCTACGGGCTTGTCACTC

103

Genbank ID: 24498

RatIL6Forward

TTCCAGCCAGTTGCCTTCTT

RatIL6Reverse

TGTTGTGGGTGGTATCCTCTGT

CX3CL1, CX3C chemokine ligand 1; CX3CR1, CX3C chemokine receptor 1; ICAM-1, intercellular adhesion molecule-1; IL-6, interleukin-6; TNF- $\alpha$, tumor necrosis factor- $\alpha$.

Table II. Experimental grouping.

Group

Treatment

Normal group (group N)

Model group (group M)

Model + ASP group (group M+A),

Model + shRNAgroup (group M+SH)

Model+overexpression group

(group $\mathrm{M}+\mathrm{CX} 3$ )

Model + ASP + shRNA group

(group $\mathrm{M}+\mathrm{A}+\mathrm{SH}$ )

Model + ASP + CX3CL1-

overexpression vector

(group $\mathrm{M}+\mathrm{A}+\mathrm{CX} 3$ )

Normal + virus control group

(group $\mathrm{N}+\mathrm{V}$ )
No treatment, cultured for $72 \mathrm{~h}$.

No treatment, cultured for $72 \mathrm{~h}$, with re-prepared thrombus added in last $12 \mathrm{~h}$.

Aspirin added at aconcentration of $5 \mathrm{mM}$. Pre-prepared thrombus added in last $12 \mathrm{~h}$.

Treated with $\mathrm{MIO}=10$ ); knockdown virus added for $72 \mathrm{~h}$, with final thrombus added in last $12 \mathrm{~h}$.

Treated with $\mathrm{MIO}=10^{\mathrm{a}}$, overexpression virus added for $72 \mathrm{~h}$, final thrombus added in last $12 \mathrm{~h}$.

Treated with $\mathrm{MIO}=10$, knockdown virus and $5 \mathrm{nM}$ aspirin added for $72 \mathrm{~h}$, with final thrombus added in the last $12 \mathrm{~h}$.

Treated with $\mathrm{MIO}=10$, overexpression virus and $5 \mathrm{nM}$ aspirin were added for $72 \mathrm{~h}$, with final thrombus added inlast $12 \mathrm{~h}$.

Adenovirus was added for $72 \mathrm{~h}$.

${ }^{\mathrm{a}} \mathrm{MIO}$ is a viral unit, 10 refers to one cell with 10 viruses.

multiple samples, and the LSD test was used for comparison among groups. $\mathrm{P}<0.05$ was considered to indicate a statistically significant difference.

\section{Results}

Thrombus-stimulated model

ELISA. ELISA was used to detect the levels of IL-6,

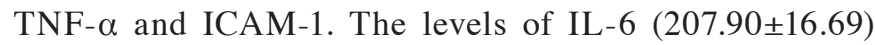

and TNF- $\alpha(239.60 \pm 15.27)$ in group $M$ was significantly increased, compared with those in group $\mathrm{N}(85.93 \pm 20.31$ and 101.23 \pm 11.91 , respectively) (all $\mathrm{P}<0.01$ ); whereas there was no difference in the level of ICAM-1 between group N $(1.44 \pm 0.15)$ and group $\mathrm{M}(1.79 \pm 0.35)$ ( $\mathrm{P}>0.05$; Fig. 1A).

$R T-q P C R$ detection. The levels ofCX3CL1 (0.00033 \pm 0.000006$)$ and CX3CR1 $(0.27 \pm 0.03)$ in group $\mathrm{N}$ were similar to those in group $\mathrm{M}(0.00020 \pm 0.000000$ and $0.35 \pm 0.04)(\mathrm{P}>0.05)$. 

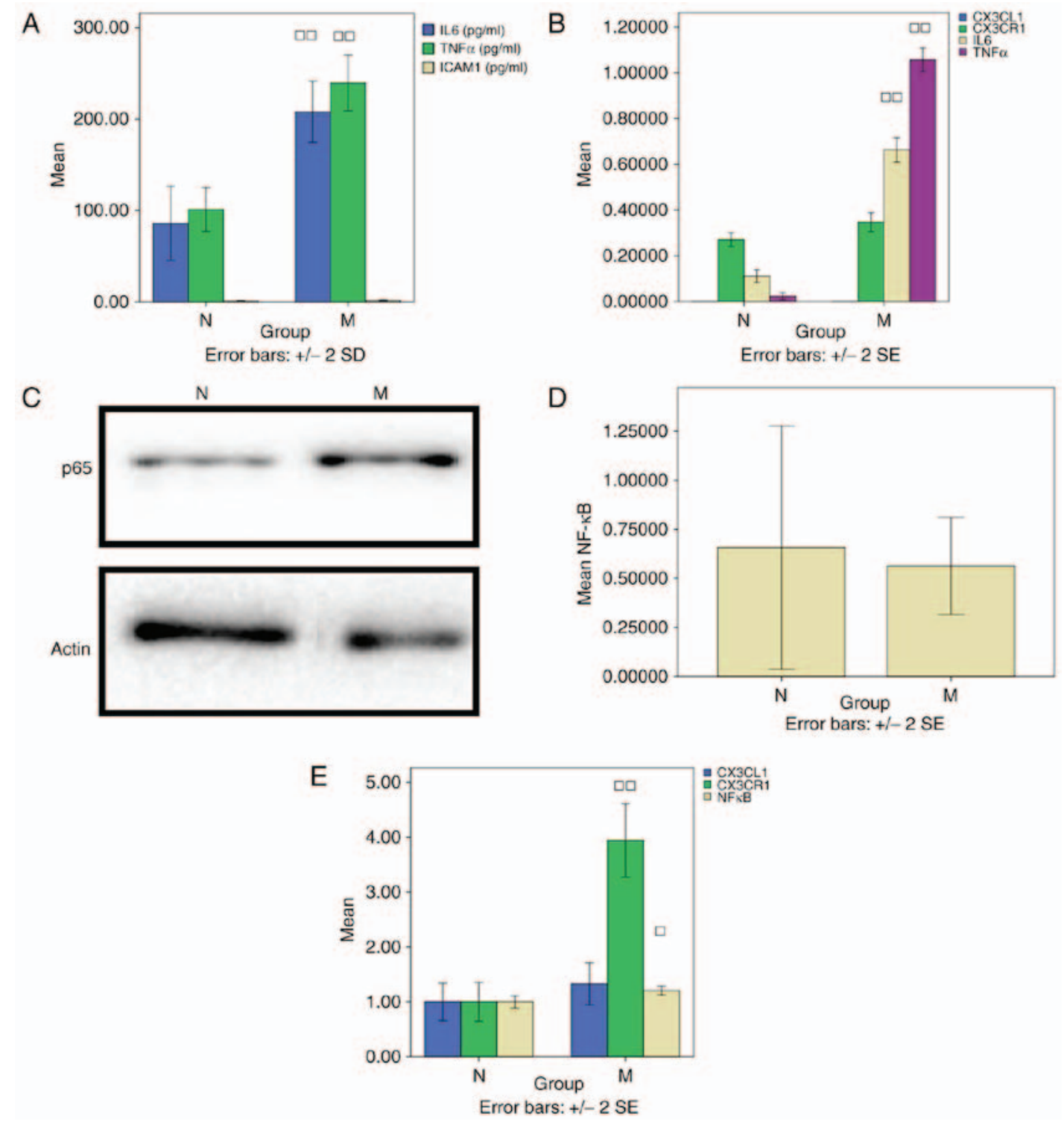

Figure 1. Thrombus-stimulated model. (A) ELISA detection of IL-6 and TNF- $\alpha$. (B) Reverse transcription-quantitative polymerase chain reaction analysis was used to detect CX3CL1, CX3CR1, IL-6 and TNF- $\alpha$. (C) Western blotting was performed to measure NF- $\mathrm{kB}$. (D) Results of western blotting for NF- $\mathrm{kB} / \mathrm{P} 65$ and $\beta$-actin proteins. ${ }^{\mathrm{P}}<0.05$ and ${ }^{\square} \mathrm{P}<0.01$, compared with group $\mathrm{N}$. (E) Laser confocal microscopy was used to evaluate the co-expression of CX3CL1/CX3CR1 and CX3CL1/NF-кB. CX3CL1, CX3C chemokine ligand 1; CX3CR1, CX3C chemokine receptor 1; IL-6, interleukin-6; TNF- $\alpha$, tumor necrosis factor- $\alpha$; $\mathrm{NF}-\kappa \mathrm{B}$, nuclear factor- $\mathrm{K} ;$;, normal; $\mathrm{M}$, model.

There was a significant difference in the level of IL-6 between groups $\mathrm{N}(0.11 \pm 0.02)$ and $\mathrm{M}(0.66 \pm 0.05)(\mathrm{P}<0.01)$. In addition, the level of TNF- $\alpha$ in group $\mathrm{N}(0.02 \pm 0.01)$ differed significantly from that in group $\mathrm{M}(1.06 \pm 0.04)(\mathrm{P}<0.01$; Fig. 1B).

Western blot analysis detection of $N F-\kappa B$. No difference in the level of $N F-\kappa B$ was found between groups $\mathrm{N}(0.66 \pm 0.62)$ and $\mathrm{M}(0.56 \pm 0.25)(\mathrm{P}>0.05$; Fig. $1 \mathrm{C}$ and $\mathrm{D})$.

Laser confocal microscopy. Laser confocal microscopy was used to evaluate the co-expression of CX3CL1/CX3CR1 and $\mathrm{CX} 3 \mathrm{CL} 1 / \mathrm{NF}-\kappa \mathrm{B}$, and to compare the cell fluorescence intensities. The level of $\mathrm{NF}-\kappa \mathrm{B}$ in group $\mathrm{N}(1.00 \pm 0.09)$ was decreased compared with that in group $\mathrm{M}(1.21 \pm 0.07)$ $(\mathrm{P}<0.05)$. Compared with group $\mathrm{N}(1.00 \pm 0.31)$, the level of CX3CR1 in group M (3.94 \pm 0.58$)$ was significantly increased $(\mathrm{P}<0.01$; Fig. 1E).
Verification of the effects of CX3CL1 on the model

ELISA detection of IL-6, TNF- $\alpha$ and ICAM-1. The level of IL-6 in group $\mathrm{N}$ was significantly decreased compared with the levels in groups $\mathrm{M}$ and $\mathrm{M}+\mathrm{CX} 3(159.27 \pm 15.02)(\mathrm{P}<0.01$; Fig. 2A). Compared with group $M$, the levels of IL-6 in groups $N$, $\mathrm{M}+\mathrm{CX} 3$ and $\mathrm{N}+\mathrm{V}(107.40 \pm 12.26)$ were decreased $(\mathrm{P}<0.01)$. The level of TNF- $\alpha$ was significantly higher in groups M, M+CX3 $(216.97 \pm 9.20)$ and $\mathrm{N}+\mathrm{V}(158.00 \pm 13.95)$, compared with that in group $\mathrm{N}(\mathrm{P}<0.01$; Fig. $2 \mathrm{~A})$. Compared with group $\mathrm{M}$, the levels of TNF- $\alpha$ were significantly decreased in groups $\mathrm{N}$ and $\mathrm{N}+\mathrm{V}$ $(\mathrm{P}<0.01)$. Compared with the group $\mathrm{N}$, there was no difference in the level of ICAM-1 in the other groups ( $\mathrm{P}>0.05$; Fig. 2A), nor was there a statistically significant difference in the level in group $\mathrm{M}+\mathrm{CX} 3(1.37 \pm 0.23)$, compared with that in group $\mathrm{M}(\mathrm{P}>0.05)$.

RT-qPCR detection of CX3CL1, CX3CR1, IL-6 and TNF- $\alpha$. Compared with groups $\mathrm{N}$ and $\mathrm{M}$, the level of CX3CL1 
A

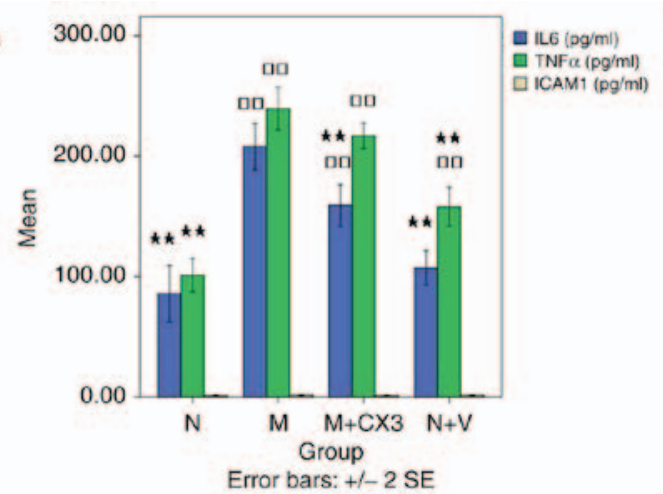

B

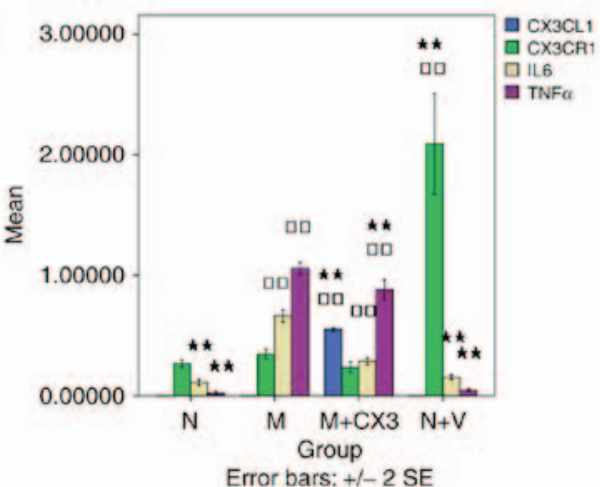

C N M
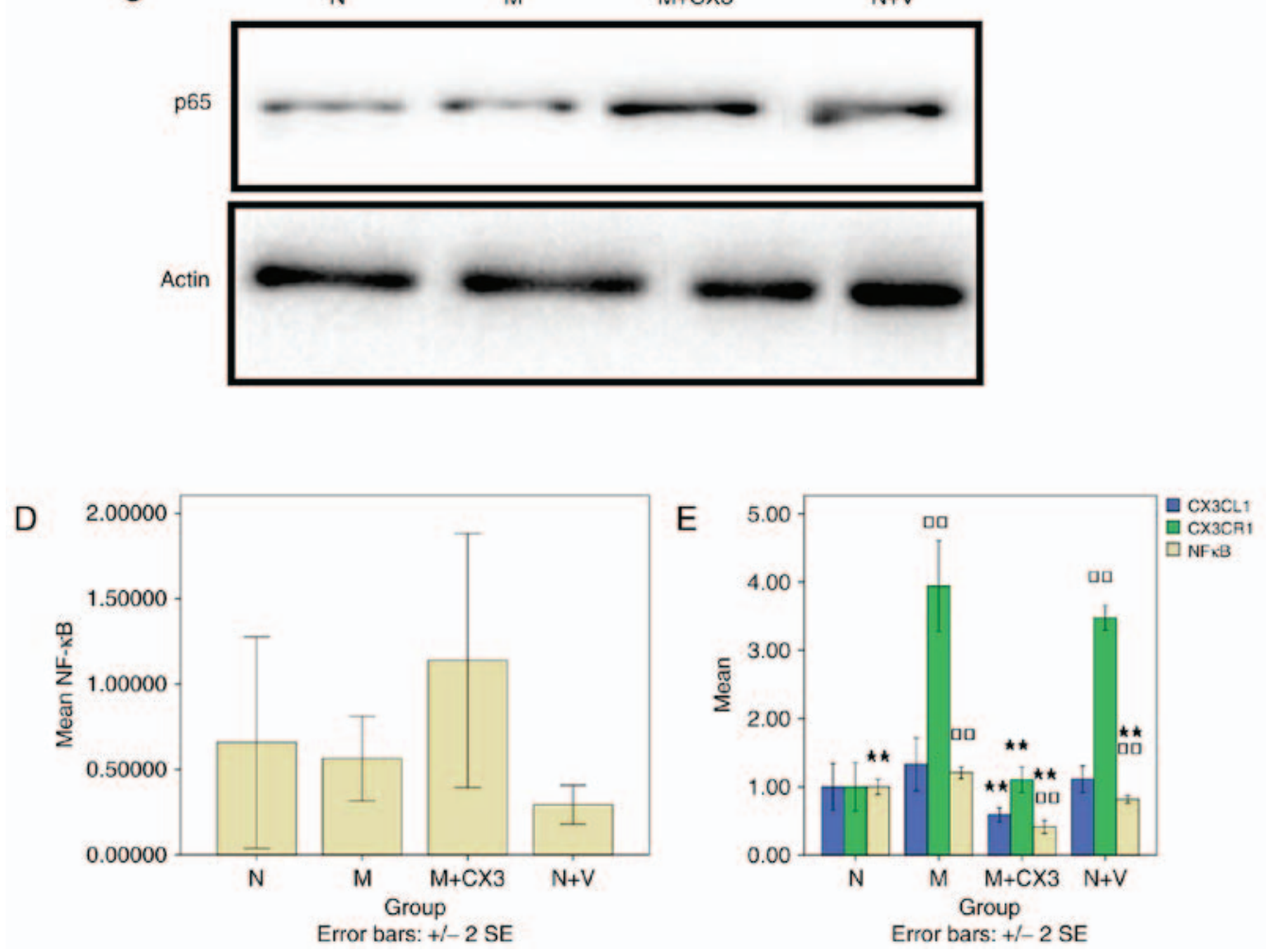

Figure 2. Effects of the overexpression of CX3CL1 on the model. (A) ELISA was used to determine levels of IL-6, TNF- $\alpha$ and ICAM-1. (B) Reverse transcription-quantitative polymerase chain reaction analysis was used to detect CX3CL1, CX3CR1, IL-6 and TNF- $\alpha$. (C) Western blotting was performed to measure $\mathrm{NF}-\kappa \mathrm{B}$. (D) Results of western blotting for $\mathrm{NF}-\kappa \mathrm{B} / \mathrm{P} 65$ and $\beta$-actin proteins. ${ }^{\square} \mathrm{P}<0.01$, compared with group $\mathrm{N}$; ${ }^{\star} \mathrm{P}<0.05$ and ${ }^{\star \star} \mathrm{P}<0.01$, compared with group M. (E) Laser confocal microscopy was used to evaluate the co-expression of CX3CL1/CX3CR1 and CX3CL1/NF- $\kappa$ B. CX3CL1, CX3C chemokine ligand 1; CX3CR1, CX3C chemokine receptor 1; IL-6, interleukin-6; TNF- $\alpha$, tumor necrosis factor- $\alpha$; ICAM-1, intercellular adhesion molecule-1; NF- $\kappa$ B, nuclear factor- $\kappa \mathrm{B} ; \mathrm{N}$, normal; M, model; M+CX3, model + CX3CL1-overexpression vector; N+V, normal + virus control.

in group $\mathrm{M}+\mathrm{CX} 3(0.55 \pm 0.01)$ was significantly increased (P<0.01; Fig. 2B). Compared with groups $\mathrm{N}$ and $\mathrm{M}$, the level of $\mathrm{CX} 3 \mathrm{CR} 1$ in group $\mathrm{N}+\mathrm{V}(2.09 \pm 0.36)$ was significantly increased $(\mathrm{P}<0.01)$. Compared with the group $\mathrm{N}$, the levels of IL-6 in groups $M$ and $M+C X 3(0.29 \pm 0.03)$ were significantly increased $(\mathrm{P}<0.01$; Fig. $2 \mathrm{~B})$. Compared with group $\mathrm{M}$, the levels of IL-6 in groups $\mathrm{N}$ and $\mathrm{N}+\mathrm{V}(0.15 \pm 0.02)$ were significantly decreased $(\mathrm{P}<0.01)$. Compared with the group $\mathrm{N}$, the levels of TNF- $\alpha$ in groups $\mathrm{M}$ and $\mathrm{M}+\mathrm{CX} 3(0.88 \pm 0.07)$ were significantly elevated $(\mathrm{P}<0.01)$. Compared with group $\mathrm{M}$, the level of TNF- $\alpha$ in groups $\mathrm{N}, \mathrm{M}+\mathrm{CX} 3$, and $\mathrm{N}+\mathrm{V}(0.05 \pm 0.01)$ were also significantly decreased ( $\mathrm{P}<0.01 ;$ Fig. $2 \mathrm{~B})$.

Western blot analysis detection of $N F-\kappa B$. Compared with groups $\mathrm{N}(0.66 \pm 0.62)$ and $\mathrm{M}(0.56 \pm 0.25)$, there was no significant difference between the levels of NF- $\kappa \mathrm{B}$ in groups $\mathrm{M}+\mathrm{CX} 3(1.14 \pm 0.74)$ and $\mathrm{N}+\mathrm{V}(0.29 \pm 0.11)(\mathrm{P}>0.05$; Fig. $2 \mathrm{C}$ and D).

Laser confocal microscopy evaluation of co-expression of $C X 3 C L 1 / C X 3 C R 1$ and $C X 3 C L 1 / N F-\kappa B$. CX3CL1 fluorescence intensity was significantly decreased in group $\mathrm{M}+\mathrm{CX} 3$ $(0.59 \pm 0.09)$ compared with that in group $\mathrm{M}(\mathrm{P}<0.01$; Fig. $2 \mathrm{E})$. The intensity of CX3CL1 fluorescence was elevated significantly in groups $\mathrm{M}$ and $\mathrm{N}+\mathrm{V}(3.47 \pm 0.16)$, compared with that in group $\mathrm{N}(\mathrm{P}<0.01)$. Compared with group $\mathrm{M}$, the intensity of CX3CL1 fluorescence was decreased significantly in groups $\mathrm{N}$ and $\mathrm{M}+\mathrm{CX} 3(1.10 \pm 0.16)(\mathrm{P}<0.01)$. No significant differences in the intensity of NF- $\mathrm{KB}$ fluorescence was observed between groups $(\mathrm{P}<0.05)$. Compared with group $\mathrm{M}$, the 

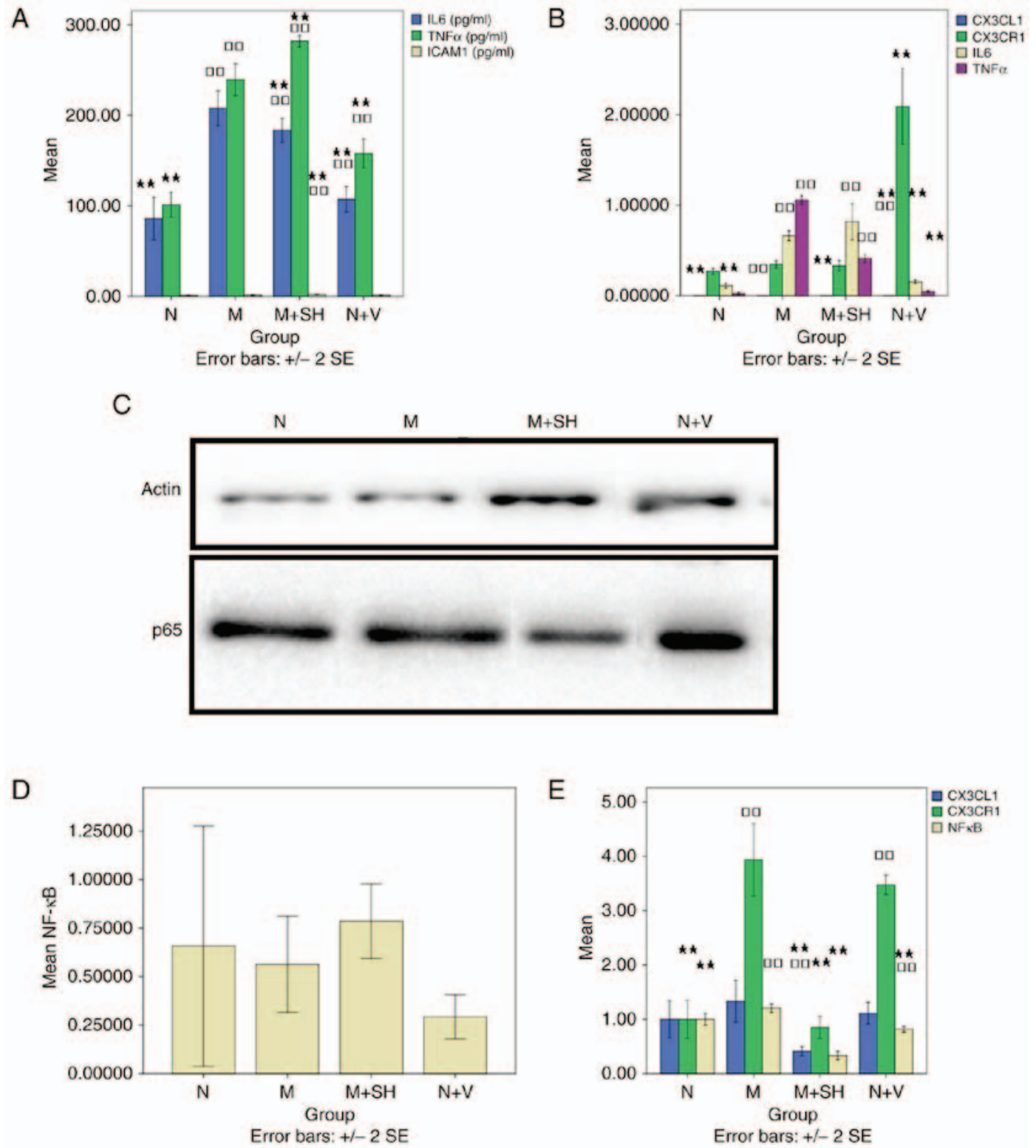

Figure 3. Effects of CX3CL1-shRNA on the model. (A) ELISA was used to determine levels of IL-6, TNF- $\alpha$ and ICAM-1. (B) Reverse transcription-quantitative polymerase chain reaction analysis was performed to analyze CX3CL1, CX3CR1, IL- 6 and TNF- $\alpha$. (C) Western blotting was used to measure NF- $\kappa$ B. (D) Results of western blotting for NF- $\mathrm{B} / \mathrm{P} 65$ and $\beta$-actin proteins. (E) Laser confocal microscopy was used to evaluate the co-expression of CX3CL1/CX3CR1 and CX3CL1/NF- $\kappa \mathrm{B} .{ }^{\square} \mathrm{P}<0.01$, compared with group $\mathrm{N} ;{ }^{\star} \mathrm{P}<0.05$ and ${ }^{\star}{ }^{\star} \mathrm{P}<0.01$, compared with group $\mathrm{M}$. CX3CL1, CX3C chemokine ligand 1 ; CX3CR1, CX3C chemokine receptor 1 ; IL-6, interleukin-6; TNF- $\alpha$, tumor necrosis factor- $\alpha$; ICAM-1, intercellular adhesion molecule-1; NF- $\kappa$ B, nuclear factor- $\kappa$; $\mathrm{N}$, normal; M, model; M+SH, model+CX3CL1-shRNA; N+V, normal + virus control.

level of $\mathrm{NF}-\kappa \mathrm{B}$ fluorescence was significantly decreased in groups $\mathrm{N}, \mathrm{M}+\mathrm{CX} 3(0.41 \pm 0.08)$ and $\mathrm{N}+\mathrm{V}(0.82 \pm 0.05)(\mathrm{P}<0.05$; Fig. 2E).

Verification of the effect of CX3CL1-shRNA on the model ELISA detection of IL-6, TNF- $\alpha$ and ICAM-1. Compared with group $\mathrm{N}$, the level of IL-6 was significantly elevated in groups $\mathrm{M}, \mathrm{M}+\mathrm{SH}(183.60 \pm 11.52)$ and $\mathrm{N}+\mathrm{V}(\mathrm{P}<0.01$; Fig. 3A). Compared with group $\mathrm{M}$, the level of IL-6 was significantly decreased in groups $\mathrm{N}, \mathrm{M}+\mathrm{SH}$, and $\mathrm{N}+\mathrm{V}(\mathrm{P}<0.01)$. Compared with group $\mathrm{N}$, the level of TNF- $\alpha$ was significantly increased in the other four groups $(\mathrm{P}<0.01$; Fig. 3A). Compared with group $\mathrm{M}$, no significant difference in the level of TNF- $\alpha$ was found between groups $\mathrm{N}, \mathrm{M}+\mathrm{SH}(282.00 \pm 5.63)$ and $\mathrm{N}+\mathrm{V}(\mathrm{P}<0.01)$. The level of ICAM-1 in group $\mathrm{M}+\mathrm{SH}(2.39 \pm 0.13)$ was higher compared withthat in group $\mathrm{N}(\mathrm{P}<0.01$; Fig. 3A). The level in group $\mathrm{M}+\mathrm{SH}$ differed significantly compared with that in group $\mathrm{M}(\mathrm{P}<0.05)$.

RT-qPCR detection of CX3CL1, CX3CR1, IL-6, and TNF- $\alpha$. The level of CX3CL1 was significantly different in groups $\mathrm{M}$ and $\mathrm{N}+\mathrm{V}(\mathrm{P}<0.05$; Fig. $3 \mathrm{~B})$. Compared with group $\mathrm{M}$, the level of CX3CL1 was significantly different in groups $\mathrm{N}$, $\mathrm{M}+\mathrm{SH}(0.000033 \pm 0.000006)$ and $\mathrm{N}+\mathrm{V}(\mathrm{P}<0.05)$. Compared with group $\mathrm{N}$, there was no significant difference in the level of CX3CR1 in group $\mathrm{M}+\mathrm{SH}(0.33 \pm 0.05)$ ( $\mathrm{P}>0.05$; Fig. 3B). Compared with group $\mathrm{M}$, the level of $\mathrm{CX} 3 \mathrm{CR} 1$ was significantly increased in group $\mathrm{N}+\mathrm{V}(\mathrm{P}<0.01)$. The level of IL-6 was significantly elevated in groups $\mathrm{M}$ and $\mathrm{M}+\mathrm{SH}(0.82 \pm 0.17)$ compared with that in group $\mathrm{N}(\mathrm{P}<0.01$; Fig. 3B). Compared 

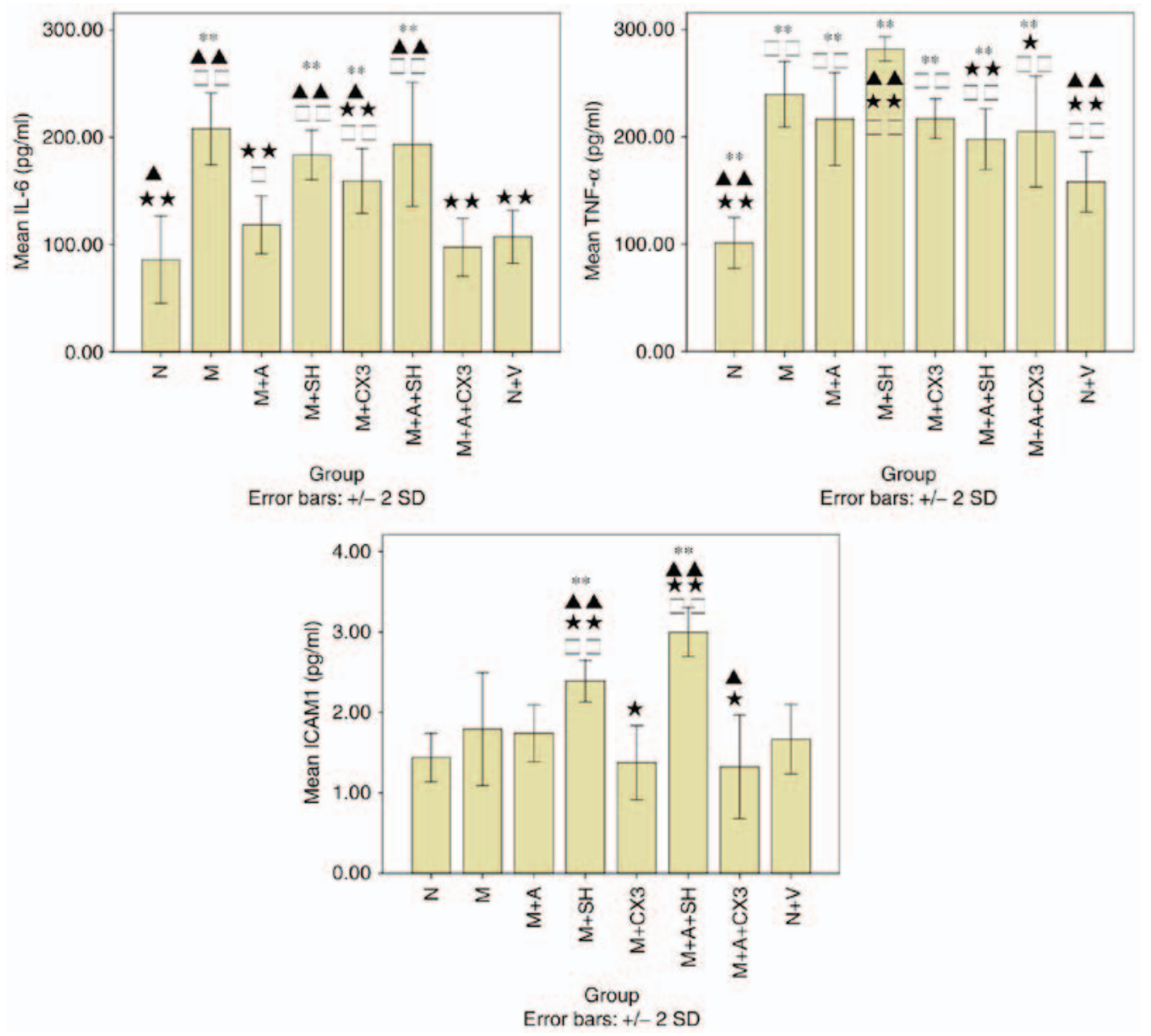

Figure 4. ELISA detection of IL-6, TNF- $\alpha$ and ICAM-1 to examine effects of aspirin combined with CX3CL1on the model. ${ }^{\square} \mathrm{P}<0.05$ and ${ }^{\square} \mathrm{P}<0.01$, compared with group $\mathrm{N}$; ${ }^{\star} \mathrm{P}<0.05$ and ${ }^{\star \star} \mathrm{P}<0.01$, compared with group $\mathrm{M}$. ${ }^{\mathbf{\Delta}} \mathrm{P}<0.05$ and ${ }^{\boldsymbol{\Delta} \mathbf{\Delta}} \mathrm{P}<0.01$, compared with group $\mathrm{M}+\mathrm{A} .{ }^{* *} \mathrm{P}<0.01$, compared with group $\mathrm{N}+\mathrm{V}$. CX3CL1, CX3C chemokine ligand 1; IL-6, interleukin-6; TNF- $\alpha$, tumor necrosis factor- $\alpha$; ICAM-1, intercellular adhesion molecule-1; N, normal; M, model; $\mathrm{M}+\mathrm{A}$, model + ASP; M+SH, model+CX3CL1-shRNA; M+CX3, model + CX3CL1-overexpression vector; M+A+SH, model + ASP + shRNA; M+A+CX3, model + ASP + CX3CL1-overexpression vector; $\mathrm{N}+\mathrm{V}$, normal + virus control.

with group $\mathrm{M}$, the level of IL-6 was decreased significantly in groups $\mathrm{N}$ and $\mathrm{N}+\mathrm{V}(\mathrm{P}<0.01)$. The level of $\mathrm{TNF}-\alpha$ was increased significantly in groups $\mathrm{M}$ and $\mathrm{M}+\mathrm{SH}(0.41 \pm 0.04)$ compared with that in group $\mathrm{N}(\mathrm{P}<0.01$; Fig. $3 \mathrm{~B})$. Compared with group $\mathrm{M}$, the level of TNF- $\alpha$ different significantly in groups $\mathrm{N}, \mathrm{M}+\mathrm{SH}$ and $\mathrm{N}+\mathrm{V}(\mathrm{P}<0.01)$.

Western blot analysis for the detection of $N F-\kappa B$ toverify the effect of CX3CL1-shRNA on the model. Compared with groups $\mathrm{N}(0.66 \pm 0.62)$ and $\mathrm{M}(0.56 \pm 0.25)$, no significant differences were found in groups $\mathrm{M}+\mathrm{SH}(0.79 \pm 0.19)$ and $\mathrm{N}+\mathrm{V}$ (0.29 \pm 0.11$)(\mathrm{P}>0.05$; Fig. 3C and D).

Evaluation of the co-expression of CX3CL1/CX3CR1 and $C X 3 C L 1 / N F-\kappa B$ by laser confocal microscopy. Compared with groups $\mathrm{N}$ and $\mathrm{M}$, the intensity of CX3CL1 fluorescence was significantly decreased in group $\mathrm{M}+\mathrm{SH}(0.41 \pm 0.07)(\mathrm{P}<0.01$; Fig. 3E). Compared with group $\mathrm{N}$, the intensity of CX3CR1 fluorescence was significantly elevated in groups $\mathrm{M}$ and $\mathrm{N}+\mathrm{V}$ $(\mathrm{P}<0.01$; Fig. 3E). Compared with group M, CX3CR1 fluorescence was significantly decreased in groups $\mathrm{N}$ and $\mathrm{M}+\mathrm{SH}$ $(0.85 \pm 0.18)(\mathrm{P}<0.01$; Fig. $3 \mathrm{E}) . \mathrm{NF}-\kappa \mathrm{B}$ fluorescence intensity was significantly different in groups $\mathrm{M}, \mathrm{M}+\mathrm{SH}(0.33 \pm 0.7)$ and $\mathrm{N}+\mathrm{V}$, compared with that in group $\mathrm{N}(\mathrm{P}<0.05)$. Compared with group $\mathrm{M}, \mathrm{NF}-\kappa \mathrm{B}$ fluorescence intensity was significantly decreased in the other three groups $(\mathrm{P}<0.05)$.

ELISA detection of IL-6, TNF- $\alpha$ and ICAM-1 (Fig. 4). Compared with group N, the level of IL-6 was significantly increased in groups $\mathrm{M}(\mathrm{P}<0.01), \mathrm{M}+\mathrm{A}(118.50 \pm 13.56)(\mathrm{P}<0.05)$, $\mathrm{M}+\mathrm{SH}(\mathrm{P}<0.01), \mathrm{M}+\mathrm{A}+\mathrm{SH}(193.53 \pm 28.86 ; \mathrm{P}<0.01)$ and $\mathrm{M}+\mathrm{CX} 3$ $(\mathrm{P}<0.01)$. Compared with group $\mathrm{M}$, the level of IL-6 was decreased in groups $\mathrm{N}, \mathrm{M}+\mathrm{A}, \mathrm{M}+\mathrm{CX} 3, \mathrm{M}+\mathrm{A}+\mathrm{CX} 3(97.63 \pm 13.57)$ and $\mathrm{N}+\mathrm{V}$ $(\mathrm{P}<0.01)$. Compared with group $\mathrm{M}+\mathrm{A}$, a significant difference in the level ofIL-6 was found in groups $\mathrm{N}(\mathrm{P}<0.05), \mathrm{M}(\mathrm{P}<0.01)$, $\mathrm{M}+\mathrm{SH}(\mathrm{P}<0.01), \mathrm{M}+\mathrm{CX} 3(\mathrm{P}<0.05)$ and $\mathrm{M}+\mathrm{A}+\mathrm{SH}(\mathrm{P}<0.01)$. Compared with group $\mathrm{N}+\mathrm{V}$, the level of IL-6 differed significantly in groups $\mathrm{M}, \mathrm{M}+\mathrm{SH}, \mathrm{M}+\mathrm{A}+\mathrm{SH}$ and $\mathrm{M}+\mathrm{CX} 3(\mathrm{P}<0.01)$.

Compared with group $\mathrm{N}$, the level of TNF- $\alpha$ was significantly increased in the other seven groups $(\mathrm{P}<0.01)$. Compared with group $\mathrm{M}$, there was significant difference in groups $\mathrm{N}(\mathrm{P}<0.01), \mathrm{M}+\mathrm{SH}(\mathrm{P}<0.01), \mathrm{M}+\mathrm{A}+\mathrm{SH}(197.90 \pm 14.19$; $\mathrm{P}<0.01), \mathrm{M}+\mathrm{A}+\mathrm{CX} 3(205.07 \pm 25.81 ; \mathrm{P}<0.05)$ and $\mathrm{N}+\mathrm{V}$ $(\mathrm{P}<0.01)$. Compared with group $\mathrm{M}+\mathrm{A}(216.67 \pm 21.60)$, there was a significant difference in groups $\mathrm{N}, \mathrm{M}+\mathrm{SH}$ and $\mathrm{N}+\mathrm{V}$ $(\mathrm{P}<0.01)$. Compared with group $\mathrm{N}+\mathrm{V}$, the level of TNF- $\alpha$ was significantly increased in groups $\mathrm{M}, \mathrm{M}+\mathrm{A}, \mathrm{M}+\mathrm{SH}, \mathrm{M}+\mathrm{CX} 3$, $\mathrm{M}+\mathrm{A}+\mathrm{SH}$ and $\mathrm{M}+\mathrm{A}+\mathrm{CX} 3(\mathrm{P}<0.01)$. 

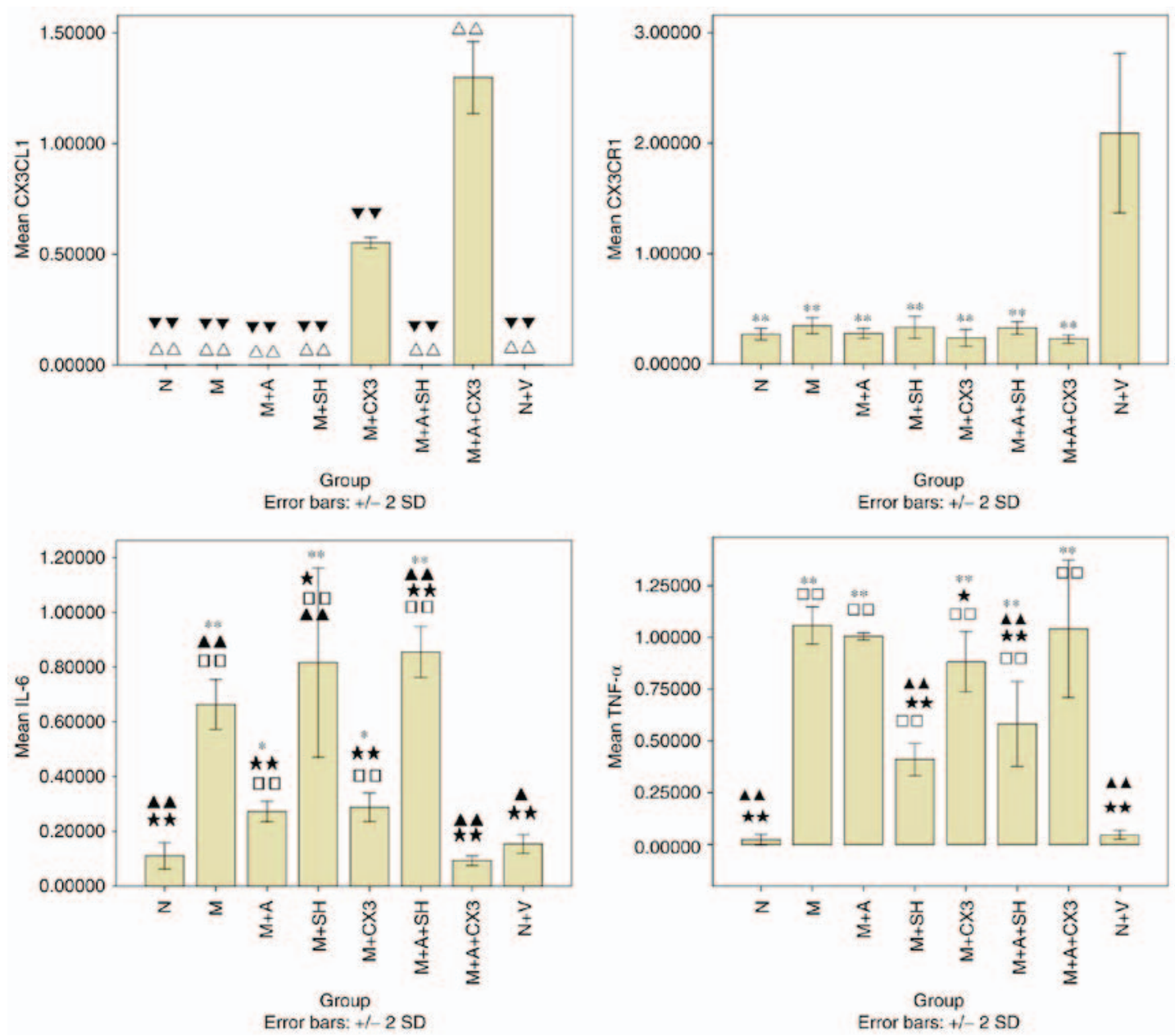

Figure 5. Reverse transcription-quantitative polymerase chain reaction analysis detection of CX3CL1, CX3CR1, IL- 6 and TNF- $\alpha$, to examine effects of aspirin combined with CX3CL1 on the model. ${ }^{\square} \mathrm{P}<0.01$, compared with group $\mathrm{N} ;{ }^{\star} \mathrm{P}<0.05$ and ${ }^{\star \star} \mathrm{P}<0.01$, compared with group $\mathrm{M}$. ${ }^{\mathbf{\Delta}} \mathrm{P}<0.05$ and ${ }^{\mathbf{\Delta}} \mathrm{P}<0.01$, compared with group $\mathrm{M}+\mathrm{A} ;{ }^{\Delta \Delta} \mathrm{P}<0.01$, compared with group $\mathrm{M}+\mathrm{CX} 3$; ${ }^{\vee} \mathrm{P}<0.01$, compared with group $\mathrm{M}+\mathrm{A}+\mathrm{CX} 3{ }^{* *} \mathrm{P}<0.01$, compared with group $\mathrm{N}+\mathrm{V}$. CX3CL1, CX3C chemokine ligand 1; CXC3CR1, CX3C chemokine receptor 1; IL-6, interleukin-6; TNF- $\alpha$, tumor necrosis factor- $\alpha$; N, normal; M, model; $\mathrm{M}+\mathrm{A}$, model + ASP; M+SH, model+CX3CL1-shRNA; M+CX3, model + CX3CL1-overexpression vector; M+A+SH, model + ASP + shRNA; M+A+CX3, model + ASP + CX3CL1-overexpression vector; $\mathrm{N}+\mathrm{V}$, normal + virus control.

Compared with group $\mathrm{N}$, the level of ICAM-1 was significantly elevated in groups $\mathrm{M}+\mathrm{SH}$ and $\mathrm{M}+\mathrm{A}+\mathrm{SH}(3.00 \pm 0.15)$ $(\mathrm{P}<0.01)$. Compared with group $\mathrm{M}$, there was a significant difference in groups $\mathrm{M}+\mathrm{SH}(\mathrm{P}<0.01), \mathrm{M}+\mathrm{A}+\mathrm{SH}(\mathrm{P}<0.01)$, $\mathrm{M}+\mathrm{CX} 3(\mathrm{P}<0.05)$ and $\mathrm{M}+\mathrm{A}+\mathrm{CX} 3(1.32 \pm 0.32 ; \mathrm{P}<0.05)$ Compared with group $\mathrm{M}+\mathrm{A}(1.74 \pm 0.18)$, there was a significant difference in the level of ICAM-1 in groups $\mathrm{M}+\mathrm{SH}(\mathrm{P}<0.01)$, $\mathrm{M}+\mathrm{A}+\mathrm{SH}(\mathrm{P}<0.01)$ and $\mathrm{M}+\mathrm{A}+\mathrm{CX} 3(\mathrm{P}<0.05)$. Compared with group $\mathrm{N}+\mathrm{V}$, the level of ICAM-1 was increased significantly in groups $\mathrm{M}+\mathrm{SH}$ and $\mathrm{M}+\mathrm{A}+\mathrm{SH}(\mathrm{P}<0.01)$.

RT-qPCR detection of CX3CL1, CX3CR1, IL-6 and TNF- $\alpha$ (Fig. 5). The level of CX3CL1 was found to differ significantly in the other seven groups, compared with that in group $\mathrm{M}+\mathrm{CX} 3$

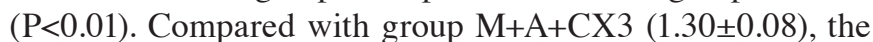
level was decreased significantly in the other seven groups $(\mathrm{P}<0.01)$. The level of CX3CR1 was decreased significantly in the other seven groups, compared with that in group $\mathrm{N}+\mathrm{V}$ $(\mathrm{P}<0.01)$. Compared with group $\mathrm{N}$, the level of IL-6 was significantly different in groups $\mathrm{M}, \mathrm{M}+\mathrm{A}(0.27 \pm 0.02), \mathrm{M}+\mathrm{SH}, \mathrm{M}+\mathrm{CX} 3$ and $\mathrm{M}+\mathrm{A}+\mathrm{SH}(0.86 \pm 0.05)(\mathrm{P}<0.01)$. Compared with group $\mathrm{M}$, the level was increased significantly in groups $\mathrm{M}+\mathrm{SH}(\mathrm{P}<0.05)$ and $\mathrm{M}+\mathrm{A}+\mathrm{SH}(\mathrm{P}<0.01)$, but was decreased in groups $\mathrm{N}(\mathrm{P}<0.01)$, $\mathrm{M}+\mathrm{A}(\mathrm{P}<0.01), \mathrm{M}+\mathrm{CX} 3(\mathrm{P}<0.01), \mathrm{M}+\mathrm{A}+\mathrm{CX} 3(\mathrm{P}<0.01)$ and $\mathrm{N}+\mathrm{V}(\mathrm{P}<0.01)$. Compared with group $\mathrm{M}+\mathrm{A}$, the level differed significantly in groups $\mathrm{N}, \mathrm{M}, \mathrm{M}+\mathrm{SH}, \mathrm{M}+\mathrm{A}+\mathrm{SH}, \mathrm{M}+\mathrm{A}+\mathrm{CX} 3$ $(0.09 \pm 0.01)$ and $\mathrm{N}+\mathrm{V}(\mathrm{P}<0.05)$. Compared with group $\mathrm{N}+\mathrm{V}$, the level differed significantly in groups $\mathrm{M}(\mathrm{P}<0.01), \mathrm{M}+\mathrm{A}$ $(\mathrm{P}<0.05), \mathrm{M}+\mathrm{SH}(\mathrm{P}<0.01), \mathrm{M}+\mathrm{A}+\mathrm{SH}(\mathrm{P}<0.01)$ and $\mathrm{M}+\mathrm{CX} 3$ $(\mathrm{P}<0.05)$. For TNF- $\alpha$, compared with group $\mathrm{N}$, the level of was increased significantly in all groups, with the exception of group $\mathrm{N}+\mathrm{V}(\mathrm{P}<0.01)$. Compared with group $\mathrm{M}$, there was a significant difference in levels between groups $\mathrm{N}(\mathrm{P}<0.01), \mathrm{M}+\mathrm{SH}$ $(\mathrm{P}<0.01), \mathrm{M}+\mathrm{CX} 3(\mathrm{P}<0.05)$ and $\mathrm{M}+\mathrm{A}+\mathrm{SH}(0.58 \pm 0.10 ; \mathrm{P}<0.01)$, $\mathrm{N}+\mathrm{V}(\mathrm{P}<0.01)$. Compared with group $\mathrm{M}+\mathrm{A}(1.01 \pm 0.04)$, there was a significant difference in levels between groups $\mathrm{N}, \mathrm{M}+\mathrm{SH}$, $\mathrm{M}+\mathrm{A}+\mathrm{SH}$ and $\mathrm{N}+\mathrm{V}(\mathrm{P}<0.01)$. Compared with group $\mathrm{N}+\mathrm{V}$, the level of TNF- $\alpha$ was increased significantly in all groups, with the exception of group $\mathrm{N}(\mathrm{P}<0.01)$.

Western blot analysis for the detection of $N F-\kappa B$ (Figs. 6 and 7). Compared with group M+CX3 (1.14 \pm 0.74$)$, the level of $\mathrm{NF}-\kappa \mathrm{B}$ was decreased significantly in group $\mathrm{M}+\mathrm{A}+\mathrm{SH}(0.47 \pm 0.30)(\mathrm{P}<0.05)$. Compared with group $\mathrm{N}+\mathrm{V}$ 


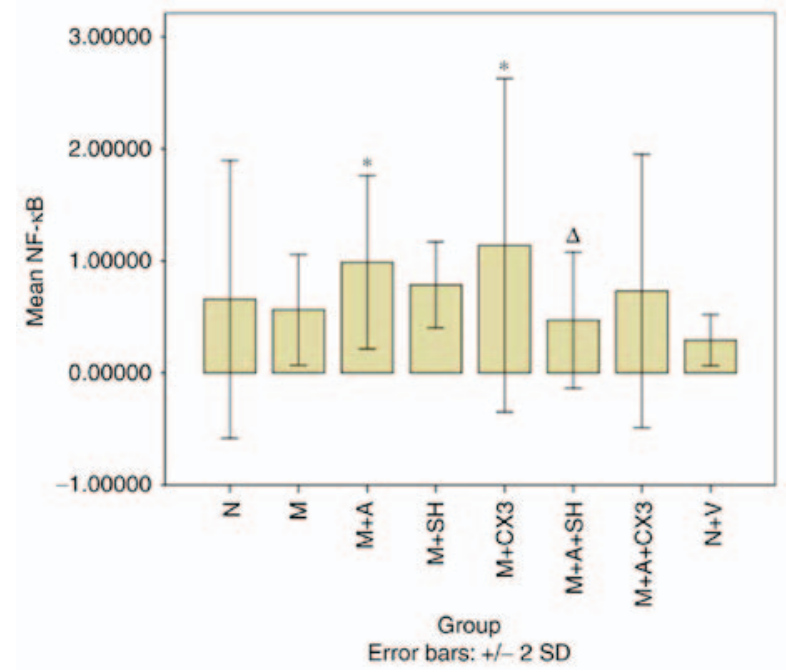

Figure 6. Western blot analysis detection of NF- $\mathrm{\kappa B}$ and determination of the effects of aspirin combined with CX3CL1 on the model. The results were analyzed comprehensively. ${ }^{\Delta} \mathrm{P}<0.05$, compared with group $\mathrm{M}+\mathrm{CX} 3$; ${ }^{*} \mathrm{P}<0.05$, compared with group $\mathrm{N}+\mathrm{V} . \mathrm{CX} 3 \mathrm{CL} 1, \mathrm{CX} 3 \mathrm{C}$ chemokine ligand 1 ; NF- $\kappa \mathrm{B}$, nuclear factor- $\kappa \mathrm{B} ; \mathrm{N}$, normal; $\mathrm{M}$, model; $\mathrm{M}+\mathrm{A}$, model + ASP; $\mathrm{M}+\mathrm{SH}$, model+CX3CL1-shRNA; M+CX3, model + CX3CL1-overexpression vector; $\mathrm{M}+\mathrm{A}+\mathrm{SH}$, model + ASP + shRNA; M+A+CX3, model + ASP + CX3CL1-ov erexpression vector; $\mathrm{N}+\mathrm{V}$, normal + virus control.

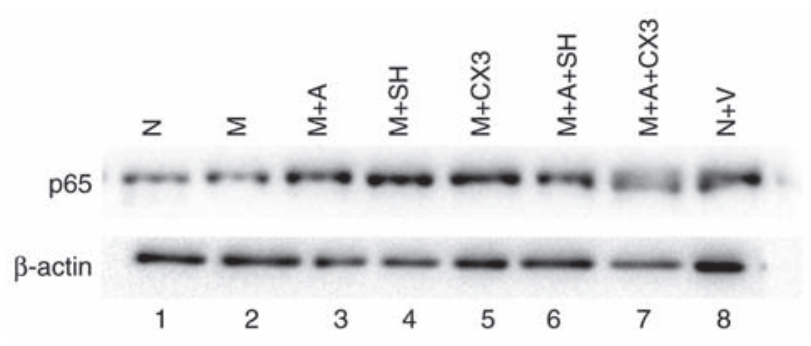

Figure 7. Results of western blot analysis of NF- $\mathrm{kB} / \mathrm{P} 65$ and $\beta$-actin proteins. 1 , group $\mathrm{N} ; 2$, group $\mathrm{M} ; 3$, group $\mathrm{M}+\mathrm{A} ; 4$, group $\mathrm{M}+\mathrm{SH}$; 5 , group $\mathrm{M}+\mathrm{CX} 3$; 6 , group $\mathrm{M}+\mathrm{A}+\mathrm{SH} ; 7$, group $\mathrm{M}+\mathrm{A}+\mathrm{CX} 3 ; 8$, group $\mathrm{N}+\mathrm{V} . \mathrm{NF}-\mathrm{\kappa B}$, nuclear factor- $\mathrm{B}$; $\mathrm{N}$, normal; M, model; M+A, model + ASP; M+SH, model+CX3CL1-shRNA; $\mathrm{M}+\mathrm{CX} 3$, model $+\mathrm{CX} 3 \mathrm{CL} 1-$ overexpression vector; $\mathrm{M}+\mathrm{A}+\mathrm{SH}$, model + ASP + shRNA; M+A+CX3, model + ASP + CX3CL1-overexpression vector; $\mathrm{N}+\mathrm{V}$, normal + virus control.

$(0.29 \pm 0.11)$, the level was significantly elevated in group $\mathrm{M}+\mathrm{CX} 3(1.14 \pm 0.74)(\mathrm{P}<0.05)$. There was no significant difference between groups $\mathrm{N}(0.66 \pm 0.62), \mathrm{M}(0.56 \pm 0.25)$ and $\mathrm{N}+\mathrm{V}$ $(0.29 \pm 0.11)(\mathrm{P}>0.05)$.

Laser confocal microscopic evaluation of the co-expression of CX3CL1/CX3CR1 and CX3CL1/NF- $\kappa B$ (Figs. 8-10). Compared with group $\mathrm{N}$, the intensity of CX3CL1 fluorescence was decreased significantly in groups $\mathrm{M}+\mathrm{SH}$ and $\mathrm{M}+\mathrm{CX} 3$ $(\mathrm{P}<0.01)$. Compared with group $\mathrm{M}$, fluorescence was significantly decreased in groups $\mathrm{M}+\mathrm{SH}, \mathrm{M}+\mathrm{CX} 3$ and $\mathrm{M}+\mathrm{A}+\mathrm{CX} 3$ $(0.80 \pm 0.17)(\mathrm{P}<0.01)$. Compared with group $\mathrm{M}+\mathrm{A}(1.49 \pm 0.19)$, fluorescence was significantly decreased in groups $\mathrm{N}(\mathrm{P}<0.01)$, $\mathrm{M}+\mathrm{SH}(\mathrm{P}<0.01), \mathrm{M}+\mathrm{CX} 3(\mathrm{P}<0.01), \mathrm{M}+\mathrm{A}+\mathrm{SH}(0.98 \pm 0.26)$ $(\mathrm{P}<0.05), \mathrm{M}+\mathrm{A}+\mathrm{CX} 3$ and $\mathrm{N}+\mathrm{V}(\mathrm{P}<0.05)$. Compared with group $\mathrm{N}+\mathrm{V}$, there was a significant difference in fluorescence between groups $\mathrm{M}+\mathrm{A}(\mathrm{P}<0.05), \mathrm{M}+\mathrm{SH}(\mathrm{P}<0.01)$ and $\mathrm{M}+\mathrm{CX} 3$ $(\mathrm{P}<0.01)$.
Compared with group $\mathrm{N}$, the intensity of CX3CR1 fluorescence was significantly elevated in groups $\mathrm{M}, \mathrm{M}+\mathrm{A}$ (2.64 \pm 0.21$), \mathrm{M}+\mathrm{A}+\mathrm{SH}(1.99 \pm 0.47), \mathrm{M}+\mathrm{A}+\mathrm{CX} 3(2.42 \pm 0.32)$ and $\mathrm{N}+\mathrm{V}(\mathrm{P}<0.01)$. Compared with group $\mathrm{M}$, fluorescence intensity was decreased significantly in groups $\mathrm{M}+\mathrm{SH}$, $\mathrm{M}+\mathrm{CX} 3$ and $\mathrm{M}+\mathrm{A}+\mathrm{CX} 3(\mathrm{P}<0.01)$. Compared with group $\mathrm{M}+\mathrm{A}$, fluorescence was significantly decreased in groups $\mathrm{N}$ $(\mathrm{P}<0.01), \mathrm{M}+\mathrm{SH}(\mathrm{P}<0.01), \mathrm{M}+\mathrm{CX} 3(\mathrm{P}<0.01)$ and $\mathrm{M}+\mathrm{A}+\mathrm{SH}$ $(\mathrm{P}<0.05)$. Compared with group $\mathrm{N}+\mathrm{V}$, a significant difference was found between all groups, with the exception of group $\mathrm{M}$ $(\mathrm{P}<0.01)$.

Compared with group N, NF- $\kappa \mathrm{B}$ fluorescence intensity was significantly different in groups $\mathrm{M}(\mathrm{P}<0.05), \mathrm{M}+\mathrm{A}(1.21 \pm 0.07$; $\mathrm{P}<0.01), \mathrm{M}+\mathrm{SH}(\mathrm{P}<0.01), \mathrm{M}+\mathrm{CX} 3 \quad(\mathrm{P}<0.01), \mathrm{M}+\mathrm{A}+\mathrm{SH}$ $(0.80 \pm 0.09 ; \mathrm{P}<0.05), \mathrm{M}+\mathrm{A}+\mathrm{CX} 3(0.68 \pm 0.06)(\mathrm{P}<0.01)$ and $\mathrm{N}+\mathrm{V}(\mathrm{P}<0.05)$. Compared with group $\mathrm{M}$, fluorescence intensity was significantly different in group $\mathrm{N}(\mathrm{P}<0.05), \mathrm{M}+\mathrm{SH}$ $(\mathrm{P}<0.01), \mathrm{M}+\mathrm{CX} 3(\mathrm{P}<0.01), \mathrm{M}+\mathrm{A}+\mathrm{SH}(\mathrm{P}<0.01), \mathrm{M}+\mathrm{A}+\mathrm{CX} 3$ $(\mathrm{P}<0.01)$ and $\mathrm{N}+\mathrm{V}(\mathrm{P}<0.01)$. Compared with group $\mathrm{M}+\mathrm{A}$, fluorescence intensity was significantly different in all groups but group $\mathrm{M}(\mathrm{P}<0.01)$. Compared with group $\mathrm{N}+\mathrm{V}$, there was a significant difference in groups $\mathrm{N}(\mathrm{P}<0.05), \mathrm{M}(\mathrm{P}<0.01), \mathrm{M}+\mathrm{A}$ $(\mathrm{P}<0.01), \mathrm{M}+\mathrm{SH}(\mathrm{P}<0.01)$ and $\mathrm{M}+\mathrm{CX} 3(\mathrm{P}<0.01)$.

\section{Discussion}

In order to elucidate the potential roles of aspirin in the inflammatory responses involving the LMVEC model, the present study investigated gene-protein and receptor-nuclear interactions. A total of four experimental stages were performed: Validation of the successful construction of a thrombus-stimulated cell model; validation of the effect of the overexpression of CX3CL1 in the model; validation of the effect of CX3CL1-inhibition in the model; and examination of the effects of aspirin combined with CX3CL1 on the model. The data from the first three experiments were derived from the fourth experiment, and the experiments were performed in triplicate.

When thrombosis occurs, damage in endothelial cells leads to an inflammatory response (2). In the initial pre-experimental stage of the present study, a thrombus-stimulated LMVEC model and a cell scratch test were used, which revealed that the inflammatory effects were more pronounced, in the former and a previous report argued that the model could be successfully manufactured (6). Accordingly, the model was improved in the present study using the instrument-specialized flow of blood to an advantage, with the experiment involving dynamic change. Subsequently, the changes in NF- $\mathrm{BB}$ B, IL-6, TNF- $\alpha$, ICAM-1, CX3CL1 and CX3CR1, generated by the stimulatory effect of the thrombus in LMVECs, were investigated, and the effects of the overexpression and inhibition of CX3CL1, or the effects of aspirin application were examined. ELISA, RT-qPCR analysis and cell fluorescence revealed that the model group secreted significantly higher levels of TNF- $\alpha$, IL-6, ICAM-1, CX3CL1, CX3CR1 and NF- $\kappa B$, compared with the control group, suggesting that the inflammatory response model of the thrombus-stimulated LMVECs had been constructed successfully.

Subsequently, the present study investigated the changes generated by the stimulatory effects of the thrombus on 


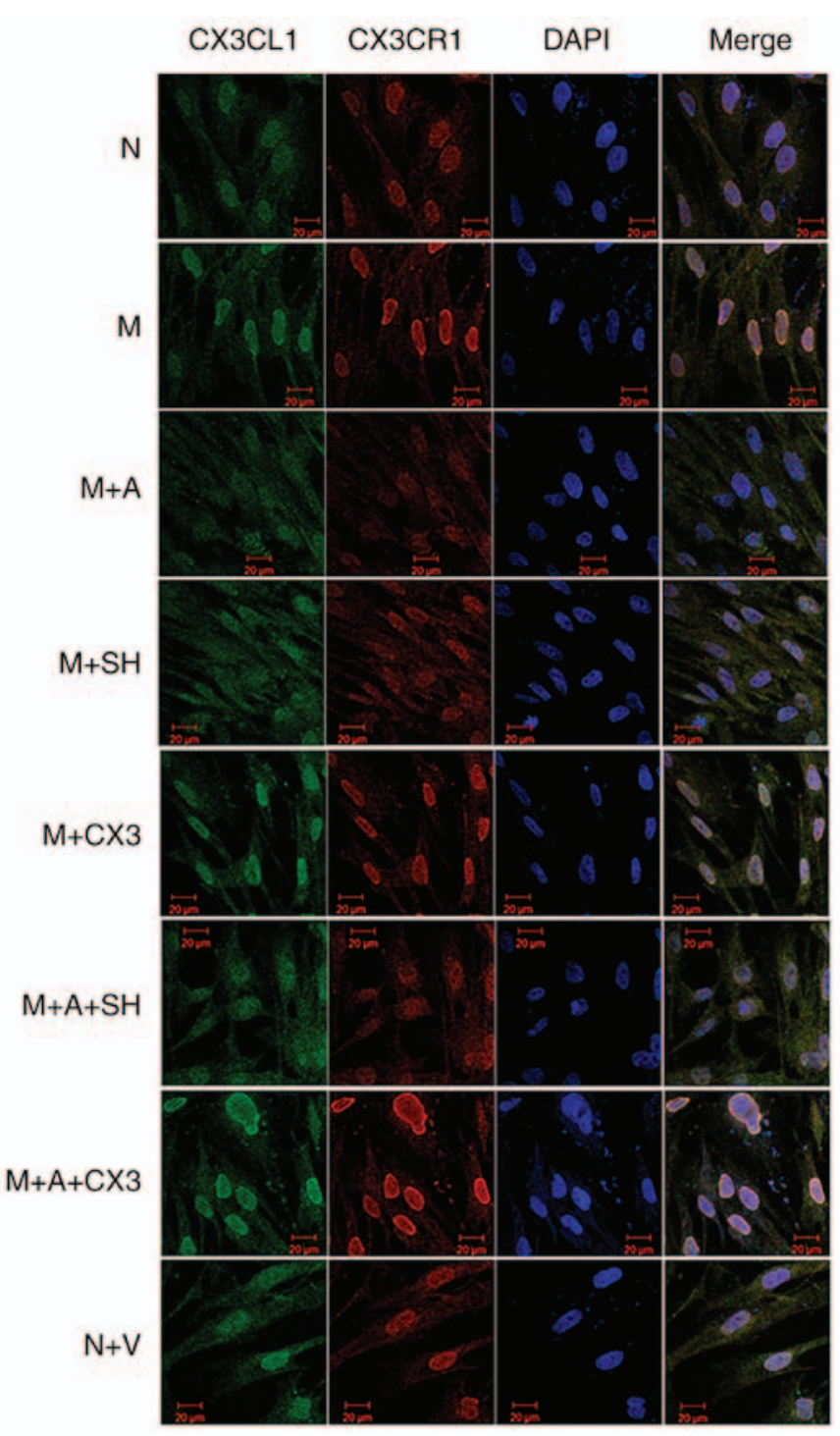

Figure 8. Laser confocal microscopy was used to evaluate the co-expression of $\mathrm{CX} 3 \mathrm{CL} 1 / \mathrm{CX} 3 \mathrm{CR} 1$. The pseudocolor for CX3CL1 was set to green, and the color for CX3CR1 was set to red. The order was as follows: Group N, $\mathrm{M}, \mathrm{M}+\mathrm{A}, \mathrm{M}+\mathrm{SH}, \mathrm{M}+\mathrm{CX} 3, \mathrm{M}+\mathrm{A}+\mathrm{SH}, \mathrm{M}+\mathrm{A}+\mathrm{CX} 3$ and $\mathrm{N}+\mathrm{V}$. CX3CL1, CX3C chemokine ligand 1; CX3CR1, CX3C chemokine receptor 1; N, normal; M, model; M+A, model + ASP; M+SH, model+CX3CL1-shRNA; M+CX3, model + CX3CL1-overexpression vector; $\mathrm{M}+\mathrm{A}+\mathrm{SH}$, model + $\mathrm{ASP}+$ shRNA; M+A+CX3, model + ASP + CX3CL1-overexpression vector; $\mathrm{N}+\mathrm{V}$, normal + virus control.

LMVECs via the overexpression of CX3CL1. It was found that, compared with the control group, the overexpression of CX3CL1 in the intervention model significantly stimulated the secretion of IL-6, TNF- $\alpha$ and CX3CL1, but had minimal effect on the expression of NF- $\mathrm{kB}$, ICAM-1 and CX3CR1.

In the third step, it was noted that the levels of IL-6, TNF- $\alpha$ and ICAM- 1 were significantly elevated in the CX3CL1-shRNA intervention model, compared with those in the control group. However, the expression levels of IL-6, ICAM-1, CX3CL1, CX3CR1 and NF- $\mathrm{BB}$ expression were significantly decreased in the model group.

Finally, the present study found that aspirin inhibited the expression of IL-6 in the model group; aspirin combined with shRNA or the overexpression of CX3CL1 inhibited the secretion of IL-6 in the model group, whereas aspirin

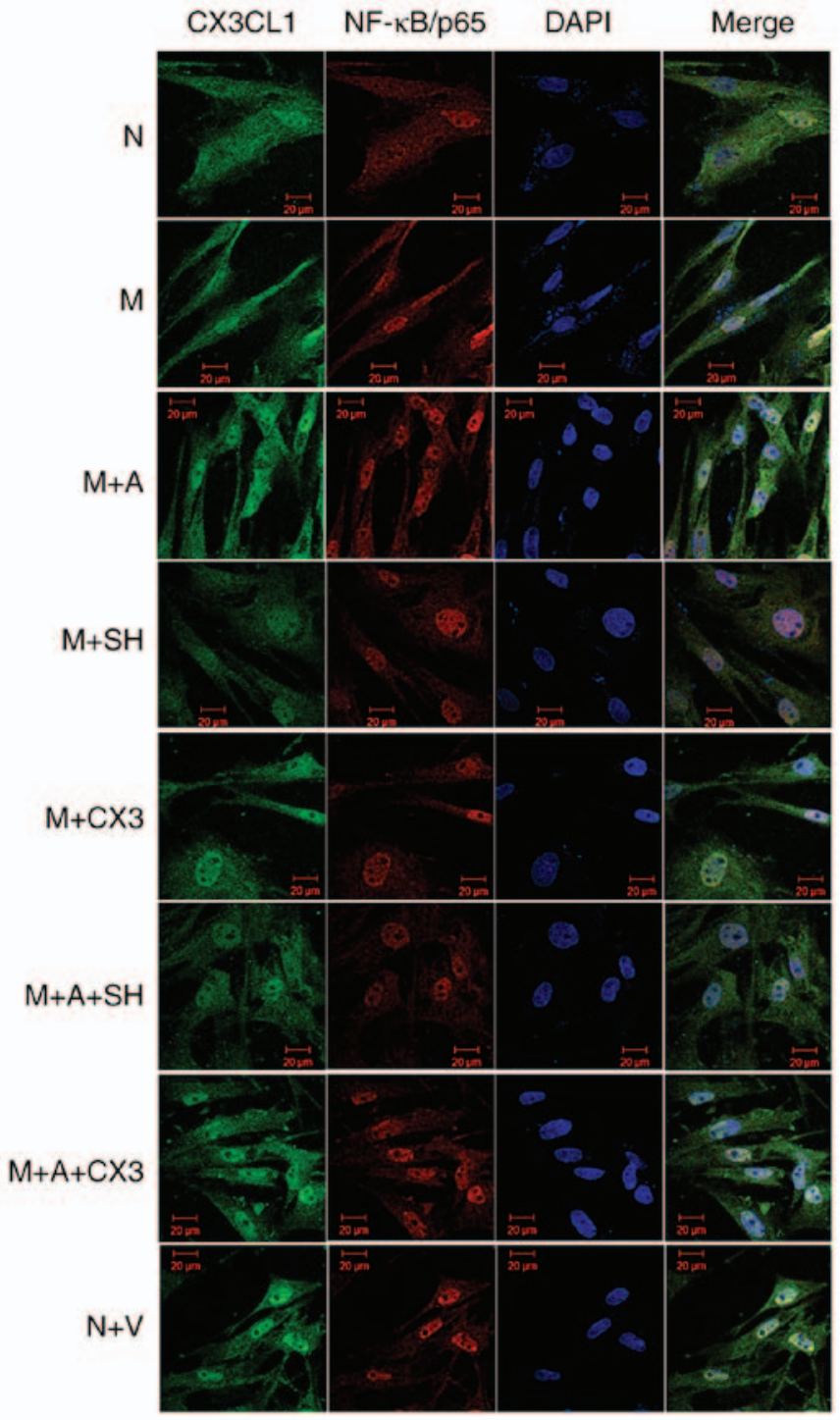

Figure 9. Laser confocal microscopy was used to evaluate the co-expression of $\mathrm{CX} 3 \mathrm{CL} 1 / \mathrm{NF}-\kappa \mathrm{B}$. The pseudocolor of CX3CL1 was set to green, and the color of NF- $\kappa \mathrm{B}$ p65 was set to red. The order was as follows: Group $\mathrm{N}, \mathrm{M}, \mathrm{M}+\mathrm{A}, \mathrm{M}+\mathrm{SH}, \mathrm{M}+\mathrm{CX} 3, \mathrm{M}+\mathrm{A}+\mathrm{SH}, \mathrm{M}+\mathrm{A}+\mathrm{CX} 3$ and $\mathrm{N}+\mathrm{V}$. CX3CL1, $\mathrm{CX} 3 \mathrm{C}$ chemokine ligand 1 ; NF- $\mathrm{KB}$, nuclear factor- $\mathrm{K}$; $\mathrm{N}$, normal; M, model; M+A, model + ASP; M+SH, model+CX3CL1-shRNA; M+CX3, model + CX3CL1-overexpression vector; $\mathrm{M}+\mathrm{A}+\mathrm{SH}$, model + ASP + shRNA $\mathrm{M}+\mathrm{A}+\mathrm{CX} 3$, model $+\mathrm{ASP}+\mathrm{CX} 3 \mathrm{CL} 1-$ overexpression vector; $\mathrm{N}+\mathrm{V}$, normal + virus control.

combined with shRNA inhibited TNF- $\alpha$ in the model group. The inhibition of CX3CL1 by shRNA in the model suggested that the construction of a CX3CL1-shRNA adenovirus vector had been successful. Aspirin, either alone or combined with shRNA, inhibited CX3CR1 in the model, with shRNA being more effective than aspirin atinhibiting CX3CR1. shRNA inhibited NF- $\mathrm{KB}$, and was more effective than aspirin at inhibiting NF- $\kappa \mathrm{B}$ in the model.

Fractalkine (CX3CL1) is the only member of the CX3C family that can bind to its specific receptor (CX3CR1) and mediate tight adhesion between inflammatory cells and vascular endothelial cells (11). CX3CL1 is important in the recruitment of inflammatory cells into the vascular wall in endothelial cell injury $(12,13)$. Previous studies have reported that TNF- $\alpha$ stimulates the CX3CL1/CX3CR1 inflammatory 

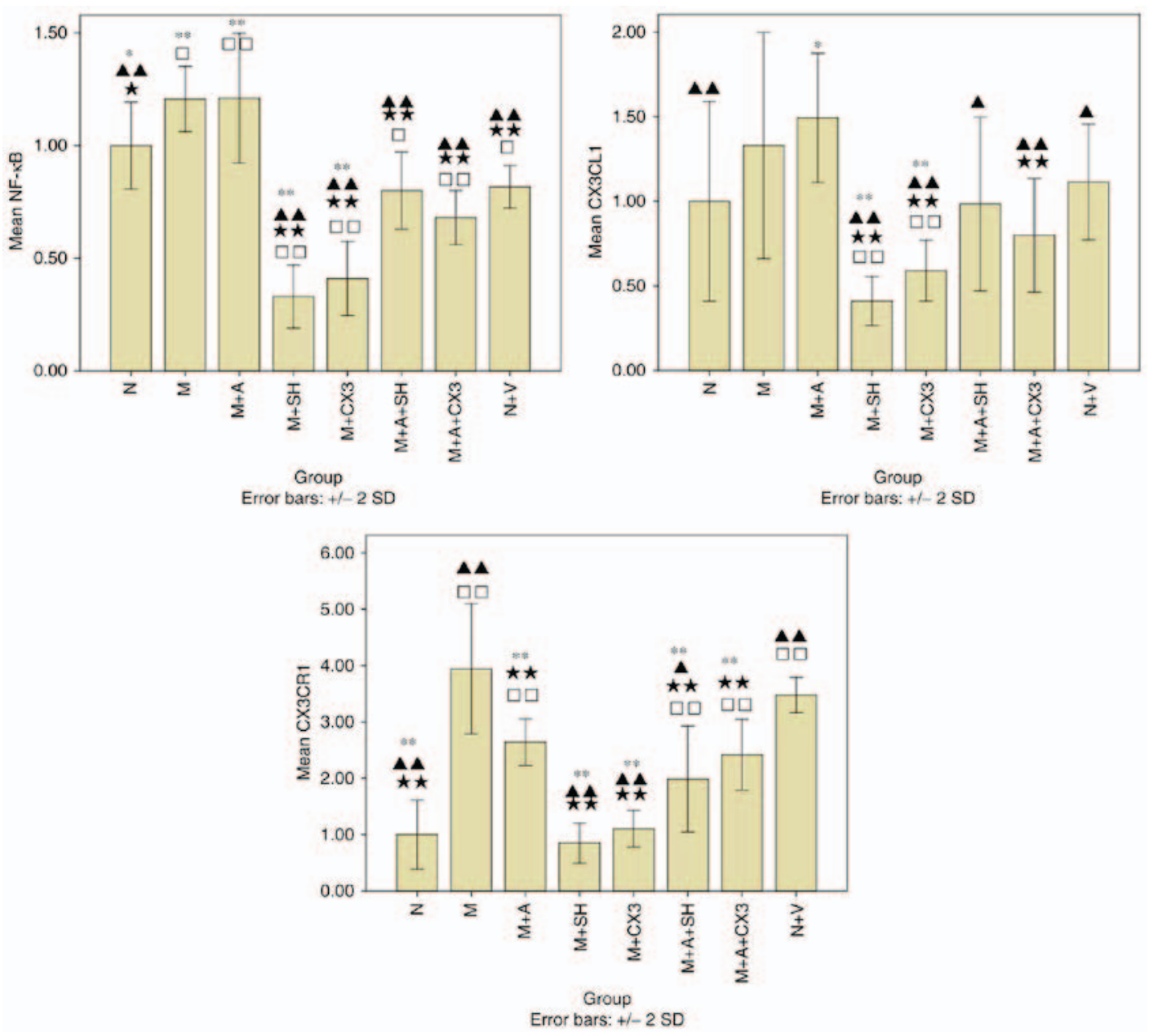

Figure 10. Laser confocal microscopy was used to evaluate the co-expression of CX3CL1/CX3CR1 and CX3CL1/NF-kB and the effect of aspirin combined with CX3CL1 on the model. ${ }^{\square} \mathrm{P}<0.05$ and ${ }^{\square} \mathrm{P}<0.01$, compared with group $\mathrm{N}$. ${ }^{\star} \mathrm{P}<0.05$ and ${ }^{\star \star} \mathrm{P}<0.01$, compared with group $\mathrm{M}$. ${ }^{\boldsymbol{}} \mathrm{P}<0.05$ and ${ }^{\boldsymbol{\Delta}}{ }^{\boldsymbol{}} \mathrm{P}<0.01$, compared with group $\mathrm{M}+\mathrm{A}$; ${ }^{*} \mathrm{P}<0.05$ and ${ }^{* *} \mathrm{P}<0.01$, compared with group $\mathrm{N}+\mathrm{V}$. CX3CL1, CX3C chemokine ligand 1; CX3CR1, CX3C chemokine receptor 1; NF- $\mathrm{kB}$, nuclear factor- $\mathrm{\kappa B}$; N, normal; M, model; M+A, model + ASP; M+SH, model+CX3CL1-shRNA; M+CX3, model + CX3CL1-overexpression vector; $\mathrm{M}+\mathrm{A}+\mathrm{SH}$, model + ASP + shRNA; M+A+CX3, model + ASP + CX3CL1-overexpression vector; N+V, normal + virus control.

signaling pathway, whereas our previous studies revealed that the expression levels of TNF- $\alpha$, CX3CL1 and CX3CR1 were significantly increased in rats with pulmonary embolism $(3,14)$. Certain studies have reported that the presence and the stimulation of the CX3CL1 receptor, CX3CR1, is correlated with the reduced release of IL-1 $\beta$ and TNF- $\alpha(15,16)$. Sukkar et al $(17)$ reported that chemokines are important in bronchial asthma and chronic obstructive pulmonary disease, with CX3CL1 acting as a chemo attractant for cell adhesion molecules, monocytes and $\mathrm{T}$ cells. The combination of interferon- $\gamma$ and TNF- $\alpha$ stimulated the mRNA and protein secretion of CX3CL1 dependent on time and concentration, whereas dexamethasone significantly promoted the secretion of CX3CL1. Studies have also reported that CX3CL1 is involved a variety of diseases, including acute severe pancreatitis, cerebral ischemia and acute hypoxia, breast cancer, rheumatoid arthritis, and increased pulmonary hypertension (18-22). The regulatory mechanisms associated with CX3CL1 may also involve $\mathrm{NF}-\kappa \mathrm{B}$. Yang et al (23) suggested that TNF- $\alpha$ promotes the adhesion of monocyte THP-1 to human umbilical vein endothelial cells via the regulation of adhesion molecules by the NF- $\mathrm{KB}$ signaling pathway, including the expression of chemokine CX3CL1/monocyte chemotactic protein-1 of ICAM/vascular cell adhesion molecule/S-select in. Cimato et al (24) found that inflammatory cytokines, rather than cholesterol, regulated the expression of CX3CL1 in atherosclerosis. Cao et al suggested that human dermal microvascular endothelial cell-1 in patients with inflammatory skin disease induced chemokines, including CXCL8, CX3CL1 and CXCL16, by activating the NF- $\mathrm{KB}$ signaling pathway when stimulated by TNF- $\alpha$, which is in agreement with our previous finding that LPS-NF- $\kappa B-C X 3 C L 1$ exists in human bronchial epithelial cells $(5,25)$. The present study revealed that CX3CL1-shRNA inhibited the secretion of NF- $\mathrm{kB}$ in the thrombus-stimulated LMVEC model, which was also consistent with a previous report (26). In addition, aspirin combined with CX3CL1-shRNA inhibited the secretion of $\mathrm{NF}-\mathrm{kB}$, further supporting our previous finding that aspirin decreased the levels of NF- $\mathrm{KB}$ in rats with pulmonary embolism (4). Our previous study found that aspirin significantly decreased pulmonary arterial pressure, improved pathological changes in embolism, and decreased the expression of CX3CL1/CX3CR1 and CX3CL1/NF- $\mathrm{KB}$, whereas the adenovirus CX3CL1-overexpression vector aggravated the inflammatory changes in APE improved 
by aspirin. In addition, the intervention of the adenovirus CX3CL1 vector reduced the changes, and its combination with aspirin significantly improved the changes (4). These in vivo experimental results were further validated in the cell experiments in the present study.

ICAM-1 belongs to an immunoglobulin superfamily, and is a transmembrane, single chain glycoprotein expressed in leukocytes, fibroblasts and epithelial cells (27). ICAM-1 can induce the expression of inflammatory factors, including IL-1 $\alpha$, IL-1 $\beta$, IL-6 and TNF- $\alpha$, via signaling pathways involving $\mathrm{NF}-\kappa \mathrm{B}$, thereby promoting the development of inflammation (28). In the present study, it was found that a significantly higher level of ICAM-1 was expressed in the model group, compared with that in the control group, and that CX3CL1-shRNA decreased the expression of ICAM-1. Aspirin did not effectively inhibit the secretion of ICAM-1 in the model group, which was consistent with a previous finding that CX3CL1 induced cell migration by upregulating the expression of ICAM-1 via the CX3CR1/PI3K/Akt/NF- $\mathrm{BB}$ pathway in human osteosarcoma cells (29).

Aspirin irreversibly inhibits cyclooxygenase, preventing the formation of thromboxane A2 in platelets (30). The substance can also have anti-inflammatory effects by preventing the activation of $\mathrm{NF}-\kappa \mathrm{B}(31)$, associated with the inhibited activation of $\mathrm{NF}-\kappa \mathrm{B}$ kinase $\beta$ by aspirin, decreasing the binding activity of $\mathrm{NF}-\kappa \mathrm{B}$ DNA (32). Studies have reported that aspirin exerts certain effects on NF- $\kappa \mathrm{B}$, IL-6, TNF- $\alpha$, ICAM-1, CX3CL1 and CX3CR1, which is consistent with the findings of the present study $(33,34)$.

As the primary mechanism underlying pulmonary embolism formation and propagation is not caused by the inflammatory response itself, future investigations are required to focus on the association between inflammation and blood coagulation following endothelial cell damage in the pulmonary vasculature.

A major limitation of the present study was that the Virchow'striad mechanism of venous thrombosis involves vascular endothelial cell injury, circulatory stasis and a hypercoagulablestate, therefore, the association between inflammation and coagulation requires further investigation.

In conclusion, the present study showed that TNF- $\alpha$, IL-6, CX3CL, CX3CR1, NF- $\kappa$ B and ICAM-1 were secreted in the thrombus-stimulated LMVEC model; the signaling pathways of CX3CL1-NF- $\kappa \mathrm{B}$, IL- 6 and TNF- $\alpha$ were important in the disease process and were partly inhibited by aspirin.

\section{Acknowledgements}

The authors of the present study would like to thank the following personnel for the collection of data: Dr Wen Feng, Dr Zhaokun Fan, Dr Ronglin Jiang (all affiliated with the Department of ICU, the First Affiliated Hospital of Zhejiang Chinese Medical University, Hangzhou, Zhejiang 310006).

\section{Funding}

This study was supported by the Natural Sciences Fund of Zhejiang Province (grant nos. LY17H290006 and LY14H290002), the Zhejiang Provincial Program for the Cultivation of High-Level Innovative Health Talents (grant no. 2014-108) and the Wenling City Key Discipline Group of Oncology (grant no. 2016-127).

\section{Availability of data and materials}

The datasets used and/or analyzed during the current study are available from the corresponding author on reasonable request.

\section{Authors' contributions}

LW proposed the study and wrote the paper. RY analyzed and interpreted the data from Thrombus-stimulated model, $\mathrm{HJ}$ analyzed and interpreted the data from verification of the effects of CX3CL1 on the model, QJ analyzed and interpreted the data from verification of the effect of CX3CL1-shRNA on the model, JK was involved in the ELISA and western blottin, ZZ was involved in the confocal microscopy, YS in was involved in reverse transcription-quantitative polymerase chain reaction, DC in was involved in the confocal microscopy and RY was involved in vector construction. All authors read and approved the final manuscript.

\section{Ethics approval and consent to participate}

All animal experiments, including the method of sacrifice, were performed in compliance with the institutional animal care regulations and guidelines of Zhejiang Chinese Medical University, and performed according to the AAALAC and the IACUC guidelines. The present study was approved by the Laboratory Animal Management and Ethical Review Committee (approval no. ZSLL-2015-1015) of Zhejiang Chinese Medical University (Hangzhou, China).

\section{Consent for publication}

Not applicable.

\section{Competing interests}

The authors declare that they have no competing interests.

\section{References}

1. Saghazadeh A, Hafizi S and Rezaei N: Inflammation in venous thromboembolism: Cause or consequence? Int Immunopharmacol 28: 655-665, 2015.

2. Deng C, Zhai Z, Wu D, Lin Q, Yang Y, Yang M, Ding H, Cao X, Zhang Q and Wang C: Inflammatory response and pneumocyte apoptosis during lung ischemia-reperfusion injury in an experimental pulmonary thromboembolism model. J Thromb Thrombolysis 40: 42-53, 2015.

3. Wang LC, Wu JN, Xia GL, Mao W, Ying RB, Huang LQ and Jiang GL: Effect of aspirin on fractalkine in rats with pulmonary embolism. Trop J Pharm Res 13: 753-760, 2014.

4. Wang LC, Jiang RL, Zhang W, Wei LL and Yang RH: Effects of aspirin on the expression of nuclear factor- $\mathrm{\kappa} B$ in a rat model of acute pulmonary embolism. World J Emerg Med 5: 229-233, 2014.

5. Jiang R, Wei L, Zhu M, Wu J and Wang L: Aspirin inhibits

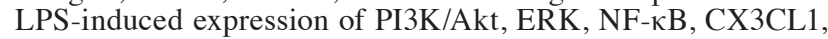
and MMPs in human bronchial epithelial cells. Inflammation 39: 643-650, 2016.

6. Felding-Habermann B, Habermann R, Saldívar E and Ruggeri ZM: Role of beta3 integrins in melanoma cell adhesion to activated platelets under flow. J Biol Chem 271: 5892-5900, 1996. 
7. Terrisse AD, Puech N, Allart S, Gourdy P, Xuereb JM, Payrastre B and Sié P: Internalization of microparticles by endothelial cells promotes platelet/endothelial cell interaction under flow. J Thromb Haemost 8: 2810-2819, 2010.

8. Liu X, Liu J, Zhao S, Zhang H, Cai W, Cai M, Ji X, Leak RK, Gao Y, Chen $\mathrm{J}$ and $\mathrm{Hu} \mathrm{X}$ : Interleukin-4 is essential for Microglia/Macrophage M2 polarization and long-term recovery after cerebral ischemia. Stroke 47: 498-504, 2016.

9. Livak KJ and Schmittgen TD: Analysis of relative gene expression data using real-time quantitative PCR and the 2(-Delta Delta C(T)) method. Methods 25: 402-408, 2001.

10. Malenovska $\mathrm{H}$ : Virus quantitation by transmission electron microscopy, $\mathrm{TCID}_{50}$, and the role of timing virus harvesting: A case study of three animal viruses. J Virol Methods 191: 136-140, 2013.

11. Bazan JF, Bacon KB, Hardiman G, Wang W, Soo K, Rossi D, Greaves DR, Zlotnik A and Schall TJ: A new class of membrane-bound chemokine with a CX3C motif. Nature 385 640-644, 1997

12. Todorova D, Sabatier F, Doria E, Lyonnet L, Vacher Coponat H, Robert S, Despoix N, Legris T, Moal V, Loundou A, et al: Fractalkine expression induces endothelial progenitor cell lysis by natural killer cells. PLoS One 6: e26663, 2011.

13. Matsumiya $T$, Ota $K$, Imaizumi $T$, Yoshida $H$, Kimura $H$ and Satoh K: Characterization of synergistic induction of CX3CL1/fractalkine by TNF-alpha and IFN-gamma in vascular endothelial cells: An essential role for TNF-alpha in post-transcriptional regulation of CX3CL1. J Immunol 184: 4205-4214, 2010.

14. Szukiewicz D, Kochanowski J, Mittal TK, Pyzlak M, Szewczyk G and Cendrowski K: CX3CL1 (fractalkine) and TNF $\alpha$ production by perfused human placental lobules under normoxic and hypoxic conditions in vitro: The importance of CX3CR1 signaling. Inflamm Res 63: 179-189, 2014.

15. Cardona AE, Pioro EP, Sasse ME, Kostenko V, Cardona SM, Dijkstra IM, Huang D, Kidd G, Dombrowski S, Dutta R, et al: Control of microglial neurotoxicity by the fractalkine receptor. Nat Neurosci 9: 917-924, 2006

16. Lyons A, Lynch AM, Downer EJ, Hanley R, O'Sullivan JB, Smith A and Lynch MA: Fractalkine-induced activation of the phosphatidylinositol-3 kinase pathway attentuates microglial activation in vivo and in vitro. J Neurochem 110: 1547-1556, 2009.

17. Sukkar MB, Issa R, Xie S, Oltmanns U, Newton R and Chung KF: Fractalkine/CX3CL1 production by human airway smooth muscle cells: Induction by IFN-gamma and TNF-alpha and regulation by TGF-beta and corticosteroids. Am J Physiol Lung Cell Mol Physiol 287: L1230-L1240, 2004

18. Li F, Zhang H, Xu KY, Wei Q and Zhou GX: Role of the chemokine fractalkine in a rat model of acute necrotizing pancreatitis and the interventional effect of ulinastatin. Arch Iran Med 16: 83-87, 2013.

19. Briones TL, Woods J and Wadowska M: Chronic neuroinflammation and cognitive impairment following transient global cerebral ischemia: Role of fractalkine/CX3CR1 signaling. J Neuroinflammation 11: 13, 2014.

20. Tsang JY, Ni YB, Chan SK, Shao MM, Kwok YK, Chan KW, Tan PH and Tse GM: CX3CL1 expression is associated with poor outcome in breast cancer patients. Breast Cancer Res Treat 140: 495-504, 2013.
21. Volin MV, Huynh N, Klosowska K, Reyes RD and Woods JM Fractalkine-induced endothelial cell migration requires MAP kinase signaling. Pathobiology 77: 7-16, 2010.

22. Ars C, Thurion P, Delos M, Sibille Y and Pilette C: Small airway obstruction in severe pulmonary arterial hypertension correlates with increased airway $\mathrm{CD} 8^{+} \mathrm{T}$-cells and fractalkine expression. Eur Respir J 34: 1494-1496, 2009.

23. Yang RC, Chang CC, Sheen JM, Wu HT, Pang JH and Huang ST: Davallia bilabiata inhibits TNF- $\alpha$-induced adhesion molecules and chemokines by suppressing IKK/NF-kappa B pathway in vascular endothelial cells. Am J Chin Med 42: 1411-1429, 2014.

24. Cimato TR and Palka BA: Fractalkine (CX3CL1), GM-CSF and VEGF-a levels are reduced by statins in adult patients. Clin Transl Med 3: 14, 2014.

25. Cao N, Chen T, Guo ZP, Qin S and Li MM: Monoammonium glycyrrhizate suppresses tumor necrosis factor- $\alpha$ induced chemokine production in HMEC-1 cells, possibly by blocking the translocation of nuclear factor-kB into the nucleus. Can J Physiol Pharmacol 92: 859-865, 2014.

26. Guo X, Pan Y, Xiao C, Wu Y, Cai D and Gu J: Fractalkine stimulates cell growth and increases its expression via NF- $\kappa \mathrm{B}$ pathway in RA-FLS. Int J Rheum Dis 15: 322-329, 2012.

27. Anbarasan C, Bavanilatha M, Latchumanadhas K and Ajit Mullasari S: ICAM-1 molecular mechanism and genome wide SNP's association studies. Indian Heart J 67: 282-287, 2015.

28. Lee SJ, Drabik K, Van Wagoner NJ, Lee S, Choi C, Dong Y and Benveniste EN: ICAM-1-induced expression of proinflammatory cytokines in astrocytes: Involvement of extracellular signal-regulated kinase and p38 mitogen-activated protein kinase pathways. J Immunol 165: 4658-4666, 2000.

29. Liu JF, Tsao YT and Hou CH: Fractalkine/CX3CL1 induced intercellular adhesion molecule-1-dependent tumor metastasis through the CX3CR1/PI3K/Akt/NF- $\mathrm{BB}$ pathway in human osteosarcoma. Oncotarget 8: 54136-54148, 2016

30. Tarantino E, Amadio P, Squellerio I, Porro B, Sandrini L, Turnu L, Cavalca V, Tremoli E and Barbieri SS: Role of thromboxane-dependent platelet activation in venous thrombosis: Aspirin effects in mouse model. Pharmacol Res 107: 415-425, 2016.

31. Zhang F, Lu M, Wang $\mathrm{H}$ and Ren T: Aspirin attenuates angiotensin II-induced inflammation in bone marrow mesenchymal stem cells via the inhibition of ERK1/2 and NF- $\mathrm{BB}$ activation. Biomed Rep 1: 930-934, 2013.

32. Stark LA, Din FV, Zwacka RM and Dunlop MG: Aspirin-induced activation of the NF- $\mathrm{BB}$ signaling pathway: A novel mechanism for aspirin-mediated apoptosis in colon cancer cells. Faseb J 15: 1273-1275, 2001.

33. Chang MC, Hung HP, Lin LD, Shyu YC, Wang TM, Lin HJ, Chan CP, Huang CC and Jeng JH: Effect of interleukin-1 $\beta$ on ICAM-1 expression of dental pulp cells: Role of PI3K/Akt, MEK/ERK, and cyclooxygenase. Clin Oral Investig 19: 117-126, 2015.

34. Szukiewicz D, Wojciechowska M, Bilska A, Stangret A, Szewczyk G, Mittal TK, Watroba M and Kochanowski J: Aspirin action in endothelial cells: Different patterns of response between chemokine CX3CL1/CX3CR1 and TNF- $\alpha$ /TNFR1 signaling pathways. Cardiovasc Drugs Ther 29: 219-229, 2015.

This work is licensed under a Creative Commons Attribution-NonCommercial-NoDerivatives 4.0 International (CC BY-NC-ND 4.0) License. 